\title{
Relation of net portal flux of nitrogen compounds with dietary characteristics in ruminants: A meta-analysis approach
}

\author{
R. Martineau,† D. Sauvant,‡ D. R. Ouellet,† C. Côrtes, † J. Vernet, ${ }^{*}$ I. Ortigues-Marty, ${ }^{\star}$ and H. Lapierre† ${ }^{1}$ \\ †Dairy and Swine Research and Development Centre, Agriculture and Agri-Food Canada, STN Lennoxville, Sherbrooke, Quebec, \\ Canada J1M 1 Z3 \\ ¥AgroParisTech INRA, 75231 Paris Cedex 05, France \\ *Institut National de la Recherche Agronomique, UR1213 Unité de Recherches sur les Herbivores, Theix, 63122 St Genès Champanelle, France
}

\begin{abstract}
Decrease of $\mathrm{N}$ intake (NI) with the aim of increasing efficiency of $\mathrm{N}$ utilization and decreasing the negative environmental effects of animal production requires assessment of the forms in which $\mathrm{N}$ is absorbed. A metaanalysis was conducted on 68 publications (90 experiments and 215 treatments) to study the effect of NI on net portal appearance (NPA) of nitrogenous nutrients [amino acids (AA), ammonia, and urea] in ruminants. In addition, the effect of several dietary energy and protein factors on this relationship was investigated. These factors were dry matter intake; proportion of concentrate; diet concentrations and intakes of nonfiber carbohydrates and neutral detergent fiber (NDF); diet concentrations of total digestible nutrients (TDN) and crude protein; rumen-degradable protein and rumenundegradable protein, as percent dry matter or percent crude protein. The effect of species and physiological stage was also investigated. Within-experiment analyses revealed that the NPA of AA-N and ammonia-N increased linearly, whereas the NPA of urea-N decreased (or recycling of urea- $\mathrm{N}$ increased) linearly with NI. Besides NI, many significant covariates could be introduced in each NPA model. However, only TDN and neutral detergent fiber intake (NDFi) were common significant covariates of NI in each NPA model. In this database, ruminants converted $60 \%$ of incremental NI into NPA of AA-N with no species effect on that slope. However, at similar NI, TDN, and NDFi, sheep absorbed more AA-N than did cattle and dairy cows. On the other hand, species tended to affect the slope of the relationship between NPA of ammonia-N and NI, which varied from 0.19 for the sheep to 0.38 for dairy cows. On average, the equivalent of $11 \%$ of incremental NI was recycled as urea-N to the gut through the portal-drained viscera, which excludes salivary
\end{abstract}

Received May 14, 2010.

Accepted February 9, 2011

${ }^{1}$ Corresponding author: Helene.Lapierre@agr.gc.ca contribution, and no species difference was detected. Overall, at similar TDN and NDFi, sheep and cattle increased their NPA of AA-N relative to NI increment by a similar magnitude. The higher absorption of AA-N observed in sheep compared with cattle, at similar NI, TDN, and NDFi, might result from lower losses of AA through portal-drained viscera metabolism.

Key words: portal, amino acid, ammonia, urea

\section{INTRODUCTION}

Decrease of $\mathrm{N}$ intake (NI) with the aim of increasing efficiency of $\mathrm{N}$ utilization and decreasing the negative environmental effects is a main goal of modern animal production. It needs, however, to be achieved through balanced rations so that true AA supply and consequent animal productivity are not compromised. A first step toward reaching this objective involves adequately defining the relationships between feed intake and composition, and availability of nitrogenous compounds to the animal. In ruminants, nutrients truly available to the animal greatly differ from nutrients ingested due to extensive rumen fermentation. The $\mathrm{N}$ digested is mainly absorbed as free AA, used by the animal for protein synthesis, or as ammonia, which needs to be detoxified by the liver into urea (Lapierre et al., 2005). Therefore, the forms in which $\mathrm{N}$ is absorbed are critical in determining the proportion of $\mathrm{N}$ digested that is available to support protein synthesis. Besides $\mathrm{N}$ intake, the recycling of arterial urea into the gut provides an additional source of $\mathrm{N}$ for microbial protein synthesis that also needs to be quantified (Lapierre and Lobley, 2001).

One way to quantify the flow of nutrients truly available to the animal is to measure the net transfer of metabolites across the portal-drained viscera (PDV; gut, spleen, pancreas, and associated mesenteric fat). Early studies describing procedures for catheter placement and blood flow measurement were reported in lambs (Katz and Bergman, 1969), beef cattle (Sniffen and Jacobson, 1975) and dairy cows (Baird et al., 1974). Since then, the technique has been used widely to study 
$\mathrm{N}$ metabolism because of the possibility of linking the 3 main forms in which $\mathrm{N}$ is absorbed across the PDV: namely AA, ammonia, and urea.

With the accumulation of data on PDV net flux of nitrogenous compounds, reviews have been published that focus mainly on the results obtained for a given species or by a given laboratory (Lapierre et al., 2005; Reynolds, 2006). Meta-analyses of studies across ruminant species and laboratories should make it possible to determine the relationship between NI and net portal appearance (NPA) of AA-N, ammonia-N, and urea-N, while controlling for study effect. Furthermore, such meta-analyses could identify the effect of dietary characteristics on the relationship between NI and these NPA. Therefore, the objective of this meta-analysis was to develop equations of NPA of AA-N, ammonia-N, and urea-N, based primarily on NI, but also controlling for other dietary factors that could influence the relationship between NI and NPA of these nitrogenous compounds.

\section{MATERIALS AND METHODS}

\section{Description of the Database}

The FLORA (flux across organs and tissues in ruminant animals) database (Vernet and Ortigues-Marty, 2006) was first used. This database pools the results of all experiments reporting splanchnic net fluxes of nutrients in sheep, beef cattle, and dairy cows. The Scopus and Current Contents Connect online bibliographic databases were queried for publications dating from 1960 to December 31, 2008. The following keywords were used: ruminant, sheep, ovine, lamb, goat, beef, steer, cattle, cow, calf, calves, and heifer, and portal, PDV, splanchnic, arterio-venous difference, and hepatic output. The criteria for inclusion of a publication in the database were: reporting NI and at least one NPA (i.e., AA-N, ammonia-N, or urea-N), presenting the results of 2 or more treatments, and presence of sufficient information to reconstitute the ration with NRC (2001). Publications were not included in the database if treatments consisted of infusion or injection of nitrogenous compounds or VFA in the mesenteric, jugular, or femoral vein, as well as in the rumen, abomasum, or small intestine. Neither were included treatments using metabolism modifiers (e.g., insulin, ionophore, plhorizin, growth hormone releasing factor, and clenbuterol), treatments subjected to abnormal feeding conditions or schedule (e.g., morning vs. night feeding, every $2 \mathrm{~h}$ vs. once or twice per day feeding, fasting, oscillating diet, non-steady-state feeding, condensed tannin inactivator, slow-release urea source, and feed contaminated with toxins), and treatments associated with physiological stress (e.g., parasitism and thermal stress). Furthermore, data presented on a regression basis with no numerical data were not included in the database. Finally, the database used for this meta-analysis consisted of 215 treatments from 68 publications obtained from 18 different scientific journals, conference proceedings, and theses or dissertations. The list of these publications is available in the Appendix and a description of the database is presented in Table 1.

\section{Selection of Variables}

Previous meta-analyses have indicated that NI was a driving force in $\mathrm{N}$ metabolism (Castillo et al., 2000; Yan et al., 2006). Although, the correlations between NPA of nitrogenous compounds and NI may not be as good as those obtained with other parameters such as $\mathrm{N}$ digested or MP supply (Lapierre et al., 2005), these parameters were either not measured or would have relied on a single empirical predictive model. Therefore, each NPA was regressed as a function of NI (i.e., the predictor of interest) and other covariates that could be qualitative or quantitative.

Qualitative Covariates. The qualitative covariates selected were species (i.e., sheep, cattle, or dairy cows) and physiological stage of cattle and sheep (i.e., growing or adult). Dairy cows were separated from cattle because of their different physiological status and level of intake relative to maintenance. Physiological stage of cattle and sheep was categorized on the basis of their BW. Cattle (i.e., growing or finishing cattle including both beef and dairy breeds) and sheep had a large range of BW because research has been carried out on growing as well as on adult animals (Table 1). Therefore, these species were divided into 2 subcategories (i.e., sheep below or above $50 \mathrm{~kg}$; cattle below or above 350 $\mathrm{kg}$ ) to characterize physiological stage, because it could not be properly assessed in each publication. The BW threshold used to subcategorize physiological stages corresponded to a BW area for which few experiments were found.

Quantitative Covariates. The quantitative covariates were related to the chemical composition of the diet and to their intake. They were selected because of their metabolic links with the NPA and the relative ease of measuring or estimating them using the NRC (2001) model. The covariates selected were DMI (g/d per $\mathrm{kg}$ of $\mathrm{BW}$ ), the proportion of concentrate (CONC; $\%$ of DM), NFC concentration (\% of DM), and NFC intake (NFCi; g/d per kg of BW), NDF concentration (\% of DM), and intake (NDFi; g/d per kg of BW), total digestible nutrients (TDN; \% of DM) concentration calculated at $1 \times$ maintenance, $\mathrm{CP}$ concentration $(\%$ of DM), and finally RDP and RUP concentrations (\% 
Table 1. Description of animals, dietary characteristics, intake, and net portal appearance (NPA) of nitrogenous metabolites in the database ${ }^{1}$

\begin{tabular}{|c|c|c|c|c|c|c|c|c|c|c|c|c|c|c|c|}
\hline \multirow[b]{2}{*}{ Item } & \multicolumn{5}{|c|}{ Sheep } & \multicolumn{5}{|c|}{ Cattle } & \multicolumn{5}{|c|}{ Dairy cows } \\
\hline & $\mathrm{n}$ & Mean & SD & Minimum & Maximum & $\mathrm{n}$ & Mean & SD & Minimum & Maximum & $\mathrm{n}$ & Mean & $\mathrm{SD}$ & Minimum & Maximum \\
\hline \multicolumn{16}{|l|}{$\mathrm{BW}^{2}(\mathrm{~kg})$} \\
\hline Growing stage & 69 & $38^{\mathrm{b}}$ & 6 & 24 & 49 & 47 & $278^{\mathrm{a}}$ & 66 & 127 & 348 & - & - & - & - & - \\
\hline Adult stage & 40 & $66^{\mathrm{c}}$ & 14 & 50 & 97 & 22 & $427^{\mathrm{b}}$ & 37 & 392 & 522 & 37 & $619^{\mathrm{a}}$ & 54 & 475 & 713 \\
\hline \multicolumn{16}{|l|}{$\begin{array}{l}\text { Dietary characteristics }{ }^{3} \\
\text { (\% of DM) }\end{array}$} \\
\hline CONC & 109 & $24.6^{\mathrm{b}}$ & 30.1 & 0.0 & 100.0 & 69 & $55.4^{\mathrm{a}}$ & 33.6 & 0.0 & 92.0 & 33 & $46.0^{\mathrm{a}}$ & 14.7 & 11.5 & 64.0 \\
\hline NFC & 109 & $24.9^{\mathrm{c}}$ & 13.2 & 1.0 & 63.7 & 69 & $48.2^{\mathrm{a}}$ & 15.8 & 13.9 & 70.1 & 33 & $38.9^{\mathrm{b}}$ & 6.8 & 20.2 & 49.8 \\
\hline $\mathrm{NDF}$ & 109 & $56.5^{\mathrm{a}}$ & 15.1 & 12.2 & 81.0 & 69 & $29.8^{\mathrm{b}}$ & 13.6 & 12.2 & 59.2 & 37 & $34.6^{\mathrm{b}}$ & 6.1 & 24.7 & 48.0 \\
\hline TDN & 109 & $60.3^{\mathrm{b}}$ & 6.6 & 47.6 & 79.1 & 69 & $71.0^{\mathrm{a}}$ & 8.4 & 53.6 & 81.9 & 33 & $69.3^{\mathrm{a}}$ & 3.1 & 63.8 & 74.6 \\
\hline $\mathrm{CP}$ & 109 & $12.5^{\mathrm{c}}$ & 3.0 & 4.1 & 19.8 & 69 & $14.9^{\mathrm{b}}$ & 3.3 & 8.9 & 23.7 & 37 & $16.7^{\mathrm{a}}$ & 1.7 & 12.0 & 21.9 \\
\hline RDP & 109 & $8.6^{\mathrm{b}}$ & 2.6 & 2.6 & 15.9 & 69 & $10.8^{\mathrm{a}}$ & 3.3 & 5.7 & 19.9 & 33 & $10.9^{\mathrm{a}}$ & 1.9 & 6.5 & 16.1 \\
\hline RUP & 109 & $4.0^{\mathrm{b}}$ & 1.2 & 1.5 & 7.6 & 69 & $4.1^{\mathrm{b}}$ & 1.2 & 1.2 & 6.9 & 33 & $5.7^{\mathrm{a}}$ & 1.2 & 3.5 & 9.0 \\
\hline $\mathrm{RDP}(\%$ of $\mathrm{CP})$ & 109 & $67.7^{\mathrm{b}}$ & 8.5 & 42.5 & 87.2 & 69 & $71.8^{\mathrm{a}}$ & 8.8 & 50.0 & 90.5 & 33 & $65.6^{\mathrm{b}}$ & 7.5 & 42.0 & 77.3 \\
\hline RUP (\% of CP) & 109 & $32.3^{\mathrm{a}}$ & 8.5 & 12.8 & 57.5 & 69 & $28.2^{\mathrm{b}}$ & 8.8 & 9.5 & 50.0 & 33 & $34.4^{\mathrm{a}}$ & 7.5 & 22.7 & 58.0 \\
\hline Intake $^{3}$ & & & & & & & & & & & & & & & \\
\hline $\begin{array}{l}(\mathrm{i} ; \mathrm{g} / \mathrm{d} \text { per } \mathrm{kg} \text { of } \mathrm{BW}) \\
\text { DMI }\end{array}$ & 109 & $22.6^{\mathrm{b}}$ & 6.7 & 6.3 & 41.6 & 69 & $17.8^{\mathrm{c}}$ & 4.8 & 5.5 & 29.4 & 37 & $29.1^{\mathrm{a}}$ & 6.6 & 12.4 & 41.7 \\
\hline NI & 109 & $0.45^{\mathrm{b}}$ & 0.17 & 0.09 & 0.90 & 69 & $0.43^{\mathrm{b}}$ & 0.16 & 0.12 & 0.88 & 37 & $0.77^{\mathrm{a}}$ & $\begin{array}{l}0.0 \\
0.19\end{array}$ & $\begin{array}{c}12.4 \\
0.36\end{array}$ & 1.21 \\
\hline $\mathrm{NFCi}$ & 109 & $5.8^{\mathrm{c}}$ & 3.9 & 0.2 & 22.6 & 69 & $8.3^{\mathrm{b}}$ & 3.1 & 2.9 & 14.0 & 33 & $11.7^{\mathrm{a}}$ & 2.8 & 5.0 & 15.0 \\
\hline $\mathrm{NDFi}$ & 109 & $12.5^{\mathrm{a}}$ & 4.9 & 2.8 & 27.9 & 69 & $5.6^{\mathrm{c}}$ & 3.5 & 0.8 & 14.0 & 37 & $10.1^{\mathrm{b}}$ & 2.9 & 4.3 & 14.8 \\
\hline $\begin{array}{l}\text { Portal blood flow } \\
(\mathrm{L} / \mathrm{h} \text { per kg of } \mathrm{BW})\end{array}$ & 104 & $2.76^{\mathrm{a}}$ & 0.84 & 1.56 & 6.00 & 65 & $2.07^{\mathrm{b}}$ & 0.50 & 1.11 & 3.32 & 31 & $2.90^{\mathrm{a}}$ & 0.61 & 1.84 & 4.23 \\
\hline \multicolumn{16}{|l|}{$\begin{array}{l}\mathrm{NPA}^{4}(\mathrm{~g} \text { of N/d } \\
\text { per } \mathrm{kg} \text { of } \mathrm{BW})\end{array}$} \\
\hline AA-N & 103 & $0.23^{\mathrm{a}}$ & 0.12 & -0.05 & 0.50 & 60 & $0.17^{\mathrm{b}}$ & 0.14 & 0.00 & 1.05 & 22 & $0.29^{\mathrm{a}}$ & 0.10 & 0.07 & 0.48 \\
\hline Ammonia-N & 100 & $0.16^{\mathrm{b}}$ & 0.10 & 0.04 & 0.55 & 59 & $0.18^{\mathrm{b}}$ & 0.10 & 0.05 & 0.50 & 29 & $0.32^{\mathrm{a}}$ & 0.12 & 0.13 & 0.56 \\
\hline Urea-N & 86 & $-0.16^{\mathrm{b}}$ & 0.09 & -0.47 & 0.04 & 57 & $-0.11^{\mathrm{a}}$ & 0.05 & -0.24 & -0.03 & 29 & $-0.22^{\mathrm{c}}$ & 0.09 & -0.44 & -0.09 \\
\hline
\end{tabular}

${ }^{\mathrm{ac}}$ Values in the same row with a different superscript are different $(P \leq 0.05$; means separated by the Tukey test).

${ }^{1}$ Data from 215 treatments (68 publications); $\mathrm{n}=$ number of treatments. Cattle refers to growing or finishing cattle including both beef and dairy breeds

${ }^{2} \mathrm{BW}$ was separated into 2 physiological stages (i.e., growing or adult) using a cut-off value of 50 or $350 \mathrm{~kg}$ for sheep and cattle, respectively.

${ }^{3}$ Dietary characteristics and intake were calculated by additivity according to NRC (2001); CONC $=$ proportion of concentrate; TDN $=$ total digestible nutrients; NI = N intake.

${ }^{4}$ Results are corrected for differences in methods (Martineau et al., 2009). 
of $\mathrm{CP}$ and \% of DM). Parameters reported in $\mathrm{g} / \mathrm{d}$ were expressed as a function of $\mathrm{BW}^{1.0}$ to allow comparison between small and large ruminants (Table 1). Indeed, although across-species metabolic processes may be best described as a function of $\mathrm{BW}^{0.75}$ (Brody, 1945), intake as well as nutrient digestion and absorption have been shown to be similar between sheep and cattle when expressed as a function of $\mathrm{BW}^{1.0}$ (Vernet et al., 2005; Sauvant et al., 2006).

Feed ingredients as similar as possible to those reported in the publications were selected from the NRC (2001) feed library to obtain the most accurate assessment of the feeding value of each ingredient and reconstitute the ration. The chemical composition $(\mathrm{CP}$, $\mathrm{NDF}$, and ash) of each feed ingredient was used when reported. When not reported for individual ingredients, the $\mathrm{CP}, \mathrm{NDF}$, and ash composition of the total diet was calculated to be as close as possible to that reported in the paper using values from the NRC (2001) feed library for all ingredients and making adjustment to the composition of the main forage of the ration. The $\mathrm{CP}$ of the ration was reported in all of the publications, whereas NDF and ash (or OM) concentrations were not reported in 48 and $40 \%$ of the publications, respectively. Where NDF or ash were not reported, values from the NRC (2001) feed library were used.

\section{Corrections for Differences in Methods}

Differences in methods of analyzing and calculating NPA of nitrogenous nutrients introduce a systematic bias into the values reported; therefore, corrections of NPA for differences in methods were applied before performing meta-analyses, as described by Martineau et al. (2009). In the database, 23.8\% $(\mathrm{n}=45)$ and $26.6 \%(\mathrm{n}=46)$ of NPA reported on a plasma basis were recalculated on a whole-blood basis for ammonia$\mathrm{N}$ and urea-N, respectively. Net portal absorption was converted from an $\alpha$-amino- $\mathrm{N}$ basis to a total AA-N basis $(61.3 \% ; \mathrm{n}=114)$ by multiplying NPA of $\alpha$-amino- $\mathrm{N}$ by 1.3958 (Martineau et al., 2009). When the NPA of both $\alpha$-amino- $\mathrm{N}$ and individual AA were reported in the same experiment, the NPA of individual AA-N was calculated and used. Corrected data were used for the meta-analyses and are presented in the tables.

\section{Meta-Analyses}

Coding of Experiments. For publications with 2 or more experiments, the latter were separated to be individually encoded. Each experiment consisted of at least 2 treatments.

Statistical Model. Relationships between the response (i.e., NPA of AA-N, ammonia-N, or urea-N) and the explanatory variables were studied with a variancecovariance model:

$$
\begin{gathered}
Y=\alpha+\beta X+\text { species }+\alpha_{i}(\text { species }) \\
+ \text { species } \times X+e
\end{gathered}
$$

where $\alpha$ is the general intercept, $\beta$ is the slope of the relationship between $X$ and $Y$ common to all experiments, $\alpha_{i}$ is the fixed effect of experiment $i$ on the general intercept $\alpha$ nested within species, and $e$ is the random residual error term (Sauvant et al., 2008). Each NPA was regressed against NI, the covariate of interest, and outliers were identified and discarded iteratively on the basis of studentized residual errors (less than -3.0 or greater than $3.0 ; 9,7$, and 11 outliers for NPA of AA-N, ammonia- $\mathrm{N}$, and urea- $\mathrm{N}$, respectively). All models were used without weighting the observations because NPA and intake parameters were divided by the $\mathrm{BW}$ and the number of animals per treatment was small and comparable across the studies. Linear and quadratic models were fitted to the data and compared. Normality and homoscedasticity of residuals were assessed graphically (normal probability plot, studentized residuals vs. fitted values). Thorough graphical assessments were carried out at each step of the meta-analyses.

Influence of Covariates. The influence of the quantitative (i.e., dietary factors) and qualitative covariates (i.e., species and physiological stage) was assessed graphically and statistically. Once all outliers were discarded, a set of residual errors (i.e., the difference between an observed value and its corresponding fitted value) was produced with only NI in the model. These residual errors were regressed against each covariate to generate data in Tables 2, 3, and 4. Furthermore, the residual errors with NI in the model were tested on smaller data sets extracted from the whole database that excluded experiments with little intra-study variation of the covariate. The standard deviation for the covariate was determined in each experiment of the database and the minimal threshold of intra-study variation was the mean of all of these standard deviations. The use of smaller data sets, termed subdatabases, improves the ability to assess the structural form of the within-experiment relationship between the residuals and each covariate (Sauvant et al., 2008). The effect of the species and physiological stage was first tested on the whole database and, if significant, then tested on each subdatabase.

The general characteristics of the subdatabases used to test each covariate are presented in Tables 2, 3, and 4. The linear or quadratic slope $(\beta)$ of each covariate and its interaction with species, the root mean square error (RMSE), and $P$-values less than 0.20 are pre- 
Table 2. Influence of each covariate on net portal appearance of amino acid- $\mathrm{N}^{1}$

\begin{tabular}{|c|c|c|c|c|c|c|c|c|c|c|c|c|}
\hline Item & \multicolumn{7}{|c|}{ Characteristics of each subdatabase $^{2}$} & \multicolumn{2}{|c|}{ Slope ${ }^{P \text {-value }}$} & $\mathrm{RMSE}^{3}$ & \multicolumn{2}{|c|}{$P$-value ${ }^{4}$} \\
\hline CONC & 11 & 26 & 30.4 & 29.7 & 0.0 & 90.0 & 5.13 & $0.0011^{<0.01}$ & - & 0.043 & NS & NS \\
\hline NFC & 19 & 47 & 28.4 & 17.7 & 1.6 & 67.3 & 3.56 & $0.0022^{<0.01}$ & - & 0.039 & NS & NS \\
\hline $\mathrm{NDF}$ & 20 & 50 & 52.0 & 18.5 & 12.2 & 81.0 & 3.47 & $-0.0027^{<0.01}$ & - & 0.041 & NS & NS \\
\hline RUP & 27 & 70 & 4.4 & 1.6 & 1.2 & 8.2 & 0.61 & $0.0062^{0.11}$ & - & 0.036 & NS & NS \\
\hline RUP (\% of CP) & 25 & 64 & 34.8 & 10.0 & 9.5 & 54.7 & 3.77 & $0.0008^{0.18}$ & - & 0.037 & NS & NS \\
\hline \multicolumn{13}{|c|}{ Intake (i; $\mathrm{g} / \mathrm{d}$ per $\mathrm{kg}$ of $\mathrm{BW})$} \\
\hline DMI & 29 & 67 & 21.1 & 7.8 & 5.5 & 41.6 & 2.38 & $-0.0009^{\mathrm{NS}}$ & - & 0.043 & NS & NS \\
\hline NFCi & 27 & 63 & 6.9 & 3.9 & 0.3 & 17.2 & 1.26 & $0.0063^{0.02}$ & - & 0.042 & 0.104 & NS \\
\hline NDFi & 23 & 52 & 11.0 & 5.6 & 1.5 & 27.9 & 1.58 & $-0.0066^{0.01}$ & - & 0.046 & NS & NS \\
\hline
\end{tabular}

${ }^{1} P$-values $<0.20$ are reported; otherwise NS. Each covariate was tested on the residual errors of the model with $\mathrm{N}$ intake as the sole predictor. A quadratic term was included in the model only if $P \leq 0.10$.

${ }^{2}$ Characteristics of subdatabases containing only experiments in which a sufficient variation of the covariate under study was observed. Number of experiments (Exp) and treatments (Trt), mean, SD, and minimal (Min) and maximal (Max) values for each covariate are reported, as well as the cut-off SD (SDmin) used to acknowledge a sufficient variation of the covariate.

${ }^{3}$ Root mean square error.

${ }^{4} P$-value of the interaction of species $(\mathrm{Sp})$ with covariate $(\mathrm{cov})$ or covariate $\times$ covariate $\left(\operatorname{cov}^{2}\right)$. Each interaction was tested individually and included in the model if $P \leq 0.10$.

${ }^{5} \mathrm{CONC}=$ proportion of concentrate; TDN $=$ total digestible nutrients at $1 \times$ maintenance; NFCi $=$ intake of NFC; NDFi $=$ intake of NDF.

${ }^{6}$ Interaction $\mathrm{Sp} \times \mathrm{CP}$ was included in the model. Species effect on the slope of CP: $\Delta=0.0084,-0.0106$, and 0.0022 for sheep, cattle, and dairy cows, respectively.

sented. A quadratic term or an interaction with species was included in the model only if $P \leq 0.10$. The influence of a covariate was considered significant at $P \leq$ 0.05 and a tendency at $0.05<P \leq 0.10$.

Models of Net Portal Appearance. The models of net portal appearance were built first with NI as the sole predictor of interest of each NPA. Then, the covariates that showed a significant effect on the residuals were used, one by one, to generate a set of independent models. More complete models were generated using a forward procedure based on a heuristic approach (Sauvant et al., 2008), adding one by one significant and biologically meaningful covariates. The covariates that modified meaningfully the slope of NI when added to the model were retained to control for potential confounders (Kleinbaum et al., 1998). Finally, a parsimonious model with the lowest RMSE is proposed for each NPA based on biological relevance and in an attempt to include the same covariates in the predictive models for the 3 NPA.

All statistical analyses were carried out using the GLM procedure (Minitab version 16.1.1.0, 2010, Minitab Inc., State College, PA). Part of the effort of the approach used for this meta-analysis was to try to characterize covariates having an influence on the relationship between the NPA and NI, including the effect of species. Therefore, because the experimental conditions were not randomly distributed and were specific to each study, experiment was considered as a fixed factor in the models. The range of inference for this meta-analysis is, therefore, limited to the domain of the specific experiments in the data set (Sauvant et al., 2008). In the models of NPA, a quadratic term or an interaction with species was included only if $P \leq$ 0.10 and an effect was considered significant at $P \leq$ 0.05 and a tendency at $0.05<P \leq 0.10$.

The project was submitted to and approved by the Institutional Committee for Animal Care of the Sherbrooke Research Centre (Quebec, Canada), although no animals were required for this study.

\section{RESULTS AND DISCUSSION}

\section{Description of Selected Experiments and Data Sets}

Rations. A description of animals, dietary characteristics, intake, and NPA is presented by species in Table 1 . The BW of sheep and cattle were separated by physiological stages and overall averaged $( \pm \mathrm{SD})$ $48.2( \pm 16.7)$ and $325( \pm 91) \mathrm{kg}$ for sheep and cattle, respectively. Dietary characteristics differed among the species. On average, diets fed to sheep contained less energy (e.g., lower proportion of concentrate and NFC concentration) and more fiber (e.g., higher NDF concentration) than those fed to cattle and dairy cows. Sheep were fed mostly forage diets of average to low 
Table 3. Influence of each covariate on net portal appearance of ammonia- $\mathrm{N}^{1}$

\begin{tabular}{|c|c|c|c|c|c|c|c|c|c|c|c|c|}
\hline Item & \multicolumn{7}{|c|}{ Characteristics of each subdatabase $^{2}$} & \multicolumn{2}{|c|}{ Slope ${ }^{P \text {-value }}$} & $\mathrm{RMSE}^{3}$ & \multicolumn{2}{|c|}{$P$-value ${ }^{4}$} \\
\hline CONC & 14 & 36 & 33.8 & 31.2 & 0.0 & 92.0 & 4.61 & $-0.0008^{<0.01}$ & - & 0.034 & NS & NS \\
\hline $\mathrm{NFC}$ & 20 & 54 & 31.1 & 19.4 & 1.6 & 70.1 & 3.42 & $-0.0015^{<0.01}$ & - & 0.037 & NS & NS \\
\hline NDF & 20 & 52 & 49.7 & 20.4 & 12.2 & 81.0 & 3.38 & $0.0017^{<0.01}$ & - & 0.036 & NS & NS \\
\hline $\mathrm{RDP}(\%$ of $\mathrm{CP})$ & 22 & 56 & 65.4 & 9.6 & 47.5 & 90.5 & 3.38 & $0.0012^{0.03}$ & - & 0.028 & NS & NS \\
\hline \multicolumn{13}{|c|}{ Intake (i; $\mathrm{g} / \mathrm{d}$ per $\mathrm{kg}$ of $\mathrm{BW})$} \\
\hline $\mathrm{DMI}^{8}$ & 28 & 68 & 21.9 & 8.0 & 5.5 & 41.6 & 2.30 & $-0.0007^{\mathrm{NS}}$ & - & 0.032 & 0.060 & NS \\
\hline NFCi & 28 & 72 & 7.1 & 4.0 & 0.3 & 17.2 & 1.22 & $-0.0061^{<0.01}$ & - & 0.037 & NS & 0.189 \\
\hline $\mathrm{NDFi}^{9}$ & 23 & 60 & 10.6 & 5.6 & 1.5 & 27.9 & 1.30 & $0.0037^{\mathrm{NS}}$ & - & 0.043 & 0.055 & 0.183 \\
\hline
\end{tabular}

${ }^{1} P$-values $<0.20$ are reported; otherwise NS. Each covariate was tested on the residual errors of the model with $\mathrm{N}$ intake as the sole predictor A quadratic term was included in the model only if $P \leq 0.10$.

${ }^{2}$ Characteristics of subdatabases containing only experiments in which a sufficient variation of the covariate under study was observed. Number of experiments (Exp) and treatments (Trt), mean, SD, and minimal (Min) and maximal (Max) values for each covariate are reported, as well as the cut-off SD (SDmin) used to acknowledge a sufficient variation of the covariate.

${ }^{3}$ Root mean square error.

${ }^{4} P$-value of the interaction of species $(\mathrm{Sp})$ with covariate $(\mathrm{cov})$ or covariate $\times$ covariate $\left(\operatorname{cov}^{2}\right)$. Each interaction was tested individually and included in the model if $P \leq 0.10$.

${ }^{5} \mathrm{CONC}=$ proportion of concentrate; TDN $=$ total digestible nutrients at $1 \times$ maintenance; $\mathrm{NFCi}=$ intake of $\mathrm{NFC} ; \mathrm{NDFi}=$ intake of $\mathrm{NDF}$.

${ }^{6}$ Interaction $\mathrm{Sp} \times \mathrm{CP}$ was included in the model. Species effect on the slope of $\mathrm{CP}: \Delta=-0.0055,0.0008$, and 0.0046 for sheep, cattle, and dairy cows, respectively.

${ }^{7}$ Interaction $\mathrm{Sp} \times \mathrm{RDP}$ was included in the model. Species effect on the slope of RDP (\% of DM): $\Delta=-0.0082,-0.0013$, and 0.0095 for sheep, cattle, and dairy cows, respectively.

${ }^{8}$ Interaction Sp $\times$ DMI was included in the model. Species effect on the slope of DMI: $\Delta=-0.0039,0.0017$, and 0.0022 for sheep, cattle, and dairy cows, respectively.

${ }^{9}$ Interaction Sp $\times$ NDFi was included in the model. Species effect on the slope of NDFi: $\Delta=-0.0079,0.0040$, and 0.0039 for sheep, cattle, and dairy cows, respectively.

quality. Furthermore, forage was the sole ingredient in $60 \%$ of sheep diets, compared with 17 and $11 \%$ for cattle and dairy cows, respectively. Finally, most dairy cows were in lactation $(\mathrm{n}=31$ from 37 treatments) and milk production averaged $28.8 \mathrm{~kg} / \mathrm{d}$ (SD 9.6; range 15.9-47.7 kg/d). Therefore, diets of dairy cows had a narrower range of NFC, NDF, and TDN concentrations compared with diets of sheep and cattle (Table 1).

Nitrogen Intake and Net Portal Appearance of Nitrogenous Compounds. Nitrogen intake was similar for sheep and cattle on a $\mathrm{g} / \mathrm{d}$ per $\mathrm{kg}$ of BW basis. However, NI was almost twice as high $(P<0.001)$ in dairy cows due to higher DMI and CP concentration of diets offered to dairy cows compared with other species (Table 1). Other species differences were noticeable on all covariates and on the NPA values as separated using the Tukey test.

On average, the portal blood flow, expressed as $\mathrm{L} / \mathrm{h}$ per $\mathrm{kg}$ of BW, was lower in cattle than in sheep and dairy cows. The NPA of AA-N was lowest in cattle, but did not differ between sheep and dairy cows; however, the NPA of AA-N accounted for $54 \%$ of NI in sheep, whereas it represented only $37 \%$ of NI for cattle and dairy cows. The NPA of ammonia-N was similar for cattle and sheep but twice as high in dairy cows; on the other hand, NPA of ammonia-N accounted for $41 \%$ of NI with no species differences. The negative NPA of urea- $\mathrm{N}$ denotes a net transfer or recycling of urea-N from the blood into the gut. The NPA of urea-N was lowest in dairy cows and highest in cattle; the NPA of urea- $\mathrm{N}$ accounted for $42 \%$ of NI in sheep and only $28 \%$ of NI for cattle and dairy cows. All of these differences observed between species need to be investigated through meta-analyses, taking into account the differences observed in NI and diet composition between species.

Modeling N Intake and Net Portal Appearance of Nitrogenous Nutrients. Figure 1 shows that each NPA is related to NI. This raw relationship does not take into account the variations in the diets fed to the different species, which need to be accounted for with statistical models. The influence of each covariate on the within-experiment relationship between NI and each NPA is presented in Tables 2, 3, and 4. As mentioned previously, the use of smaller subdatabases improves the ability to explore the structural form of the 
Table 4. Influence of each covariate on net portal appearance of urea- $\mathrm{N}^{1}$

\begin{tabular}{|c|c|c|c|c|c|c|c|c|c|c|c|c|}
\hline Item & \multicolumn{7}{|c|}{ Characteristics of each subdatabase $^{2}$} & \multicolumn{2}{|c|}{ Slope ${ }^{P \text {-value }}$} & $\mathrm{RMSE}^{3}$ & \multicolumn{2}{|c|}{$P$-value ${ }^{4}$} \\
\hline CONC & 11 & 28 & 40.9 & 33.2 & 0.0 & 92.0 & 5.02 & $-0.00033^{0.13}$ & - & 0.029 & NS & NS \\
\hline NFC & 18 & 48 & 33.1 & 19.5 & 1.6 & 70.1 & 3.56 & $-0.00053^{0.16}$ & - & 0.029 & NS & NS \\
\hline $\mathrm{NDF}$ & 30 & 40 & 48.4 & 22.1 & 12.2 & 81.0 & 3.39 & $0.00070^{0.13}$ & - & 0.031 & NS & NS \\
\hline $\mathrm{RDP}(\%$ of $\mathrm{CP})$ & 22 & 55 & 66.0 & 9.6 & 47.5 & 90.5 & 3.50 & $-0.00020^{\mathrm{NS}}$ & - & 0.024 & 0.146 & NS \\
\hline \multicolumn{13}{|c|}{ Intake $(\mathrm{i} ; \mathrm{g} / \mathrm{d}$ per $\mathrm{kg}$ of $\mathrm{BW})$} \\
\hline DMI & 24 & 55 & 20.4 & 8.0 & 5.5 & 41.6 & 2.21 & $-0.0117^{<0.01}$ & $0.00025^{<0.01}$ & 0.038 & 0.182 & NS \\
\hline $\mathrm{NFCi}$ & 24 & 60 & 7.5 & 4.0 & 0.3 & 17.2 & 1.22 & $-0.0038^{0.03}$ & - & 0.029 & NS & NS \\
\hline NDFi & 21 & 51 & 10.3 & 5.8 & 1.5 & 27.9 & 1.35 & $-0.0059^{0.15}$ & $0.00031^{0.05}$ & 0.036 & NS & NS \\
\hline
\end{tabular}

${ }^{1} P$-values $<0.20$ are reported; otherwise NS. Each covariate was tested on the residual errors from the model with $\mathrm{N}$ intake as the sole predictor. A quadratic term was included in the model only if $P \leq 0.10$.

${ }^{2}$ Characteristics of subdatabases containing only experiments in which a sufficient variation of the covariate under study was observed. Number of experiments (Exp) and treatments (Trt), mean, SD, and minimal (Min) and maximal (Max) values for each covariate are reported, as well as the cut-off SD (SDmin) used to acknowledge a sufficient variation of the covariate.

${ }^{3}$ Root mean square error.

${ }^{4} P$-value of the interaction of species $(\mathrm{Sp})$ with covariate $(\mathrm{cov})$ or covariate $\times$ covariate $\left(\operatorname{cov}^{2}\right)$. Each interaction was tested individually and included in the model if $P \leq 0.10$.

${ }^{5} \mathrm{CONC}=$ proportion of concentrate; TDN $=$ total digestible nutrients at $1 \times$ maintenance; NFCi $=$ intake of NFC; NDFi $=$ intake of NDF.

${ }^{6}$ Interaction $\mathrm{Sp} \times \mathrm{TDN}$ and $\mathrm{Sp} \times \mathrm{TDN}^{2}$ were included in the model. Species effect on the slope of TDN: $\Delta=0.3386,0.3888$, and -0.7274 and on the slope of $\mathrm{TDN}^{2}: \Delta=-0.0023,-0.0027$, and 0.0050 for sheep, cattle, and dairy cows, respectively.

relationship between the covariate and the response, after controlling for NI. However, this approach has some drawbacks, as few studies in dairy cows showed sufficient intra-study variation for CONC, NFC, NDF, TDN, RDP, NFCi, or NDFi. Therefore, extrapolation of results to dairy cows should be done cautiously and more research should be directed toward studying the variation of these covariates in dairy cows.

In the sections below, the influence of significant covariates on each NPA (Tables 2, 3, and 4) is discussed. And finally, the complete model, including a set of common covariates for each NPA, is presented and discussed.

\section{Net Portal Appearance of AA-N}

Influence of Covariates. The effect of species was significant $(P<0.001)$ and NPA of AA-N was highest in sheep compared with cattle and dairy cows: $0.240,0.174$, and $0.134 \mathrm{~g}$ of $\mathrm{N} / \mathrm{d}$ per $\mathrm{kg}$ of $\mathrm{BW}$ for least squares means of AA-N in sheep, cattle, and dairy cows, respectively. These least squares means were calculated at mean NI $(0.466 \mathrm{~g} / \mathrm{d}$ per $\mathrm{kg}$ of BW) and are in line with the discrepancy observed between NPA of AA-N and NI among species in Table 1 . The effect of physiological stage was not significant $(0.191$ and 0.195 $\mathrm{g}$ of $\mathrm{N} / \mathrm{d}$ per $\mathrm{kg}$ of BW for LSM of AAN-N for growing and adult, respectively; $P=0.64$; LSM calculated at a mean NI of $0.422 \mathrm{~g} / \mathrm{d}$ per $\mathrm{kg}$ of BW). Therefore, only the interaction of species with other covariates will be presented in Table 2. The effect of species itself is not reported because it could not be appropriately tested using the residuals that controlled for the study effect.

Most covariates had a significant influence on the effect of NI on NPA of AA-N, except RUP as a $\%$ of DM or CP and DMI (Table 2). Energy factors (e.g., proportion of concentrate, NFC, TDN, and NFCi) were associated positively with NPA of AA-N, whereas the opposite was observed for fiber factors (e.g., NDF and NDFi). Other potential covariates related to energy could have been useful; for example, in experiments designed to study the effects of processing method and degree of processing on $\mathrm{N}$ metabolism, Alio et al. (2000) and Tagari et al. (2004) found a positive effect of processing on NPA of AA-N. However, these covariates could not be properly assessed in our data set because of an insufficient number of experiments dealing with that issue.

Regarding the other covariates studied, the CP diet concentration interacted strongly with species, the influence being slightly positive in sheep and strongly negative in cattle. However the species $\times \mathrm{CP}$ interaction and the CP main effect were no longer significant when other covariates were added in the model, particularly NDF. A deeper analysis of the meta-design of studies with variation in NDF and CP revealed that such variations were obtained differently for sheep and cattle. In cattle experiments, the variation in $\mathrm{CP}$ was 
a)

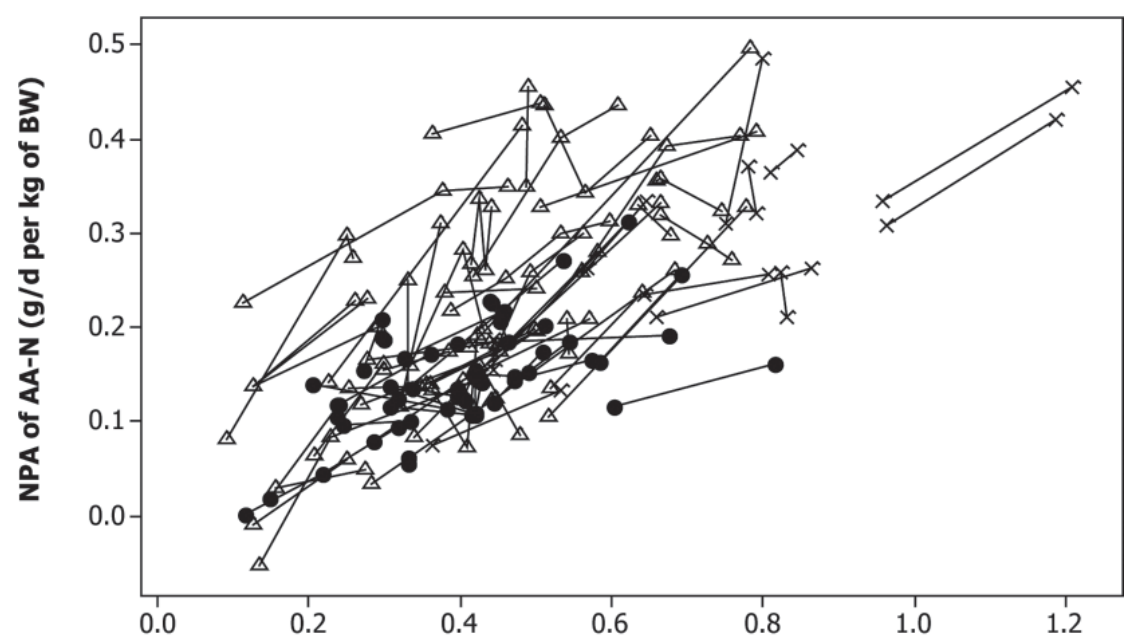

b)

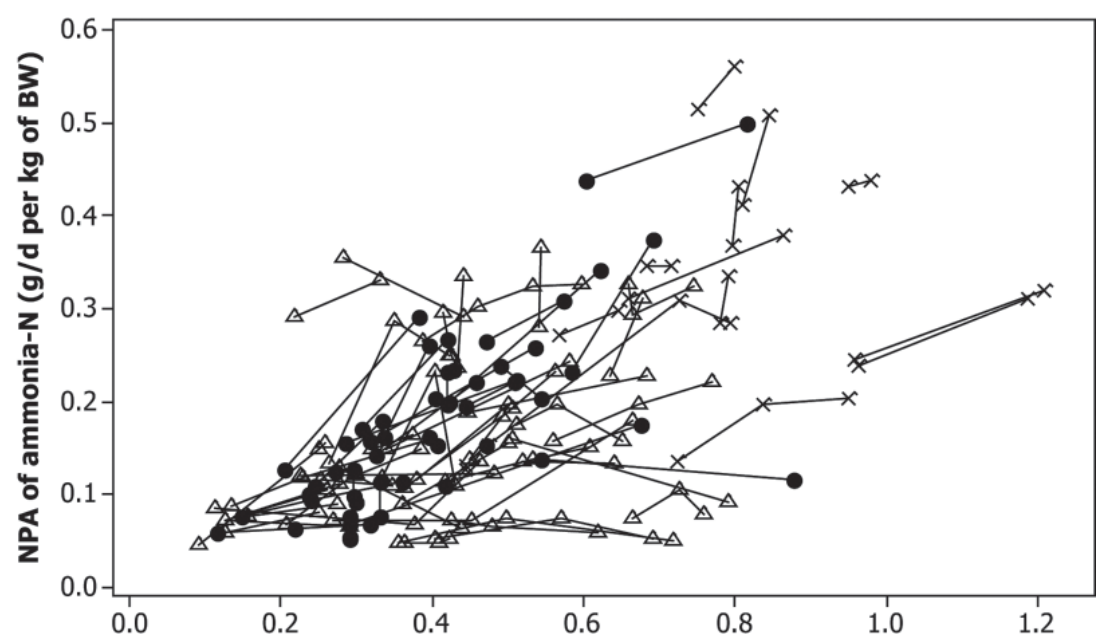

c)

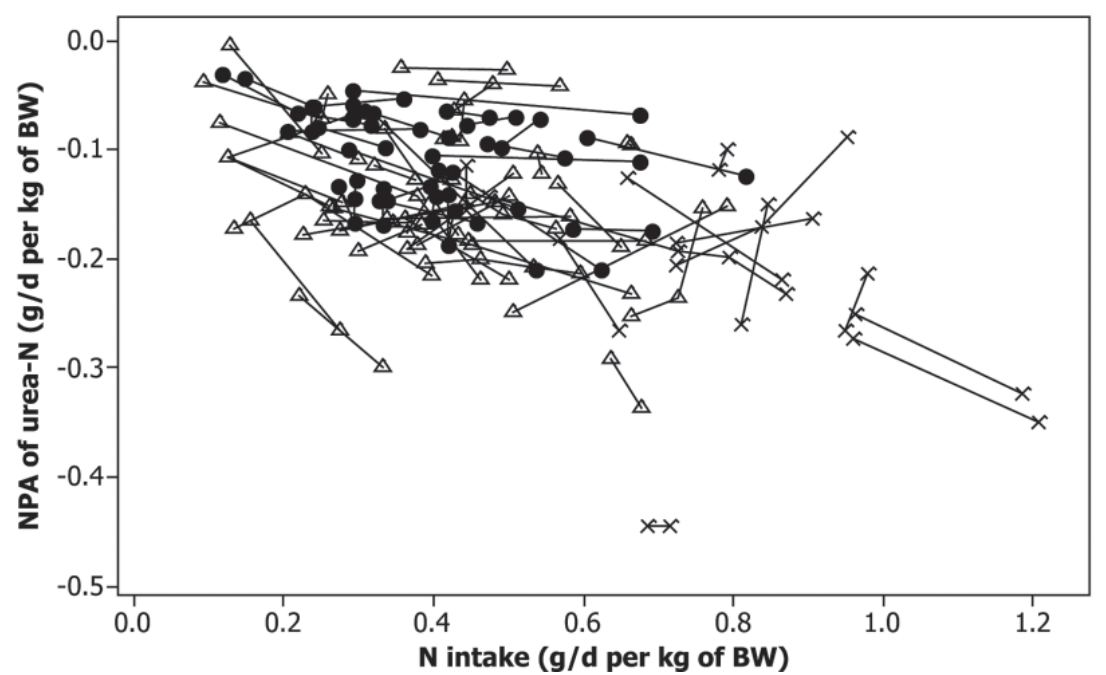

Figure 1. Within-experiment relationships of $\mathrm{N}$ intake and net portal absorption (NPA) of AA-N (a), ammonia-N (b), and urea-N (c); $\Delta$ $=$ sheep $\bullet=$ cattle; and $\times=$ dairy cows. 
obtained by diluting the ration with a concentrate (Prior et al., 1981; Reynolds and Huntington, 1988; Huntington, 1989). On the other hand, the variation in sheep experiments was obtained by diluting the ration with a concentrate (Goetsch et al., 1994; Goetsch and Ferrell, 1995; Patil et al., 1995), by feeding a high- versus a low-quality forage (Prewitt et al., 1975; Park et al., 1997), or by adding soybean meal to the forage (Krehbiel et al., 1998). As a result, in cattle, an increase in $\mathrm{CP}$ was associated with an increase in NDF, whereas, in sheep, an increase in $\mathrm{CP}$ was generally associated with a decrease in NDF (or an increase in TDN), which is positively associated with NPA of AAN. Not surprisingly, when controlling for both CP and NDF (or TDN), CP is no longer significant, as NDF or TDN are more potent covariates in the relationship between NI and NPA of AA-N.

The quality of protein fed (i.e., RUP as a $\%$ of $\mathrm{CP}$ ) was not found to be associated with NPA of AA-N in this meta-analysis. Similarly, literature findings related to the effect of RUP supplementation on NPA of AA-N have not been consistent. At similar NI across treatments, RUP (\% of CP) had a positive effect on NPA of AA-N in sheep (Bohnert et al., 1999; Rémond and Poncet, 2007) and dairy cows (Blouin et al., 2002). On the other hand, a negative effect (Han et al., 2001) or no effect was found on NPA of AA-N when the RUP concentration in the diet was increased (Cleale et al., 1987; Branco et al., 2004; Atkinson et al., 2007). Fukuma et al. (2005) reported a positive response in mature wethers fed increasing levels of RUP through dietary fishmeal supplementation; however, NI increased with the level of fishmeal supplementation, such that no difference could be found among treatments in the residuals (i.e., at equal NI). Overall, RUP per se may not be a major factor associated with NPA of AA-N if availability of degradable $\mathrm{N}$ adversely affects microbial protein synthesis.

Model of NPA of $\boldsymbol{A A}-\boldsymbol{N}$. Based on information gained with the previous analyses, a general NPA model was developed using the whole database. The final model for each NPA was based on the best fit to the data (i.e., lowest RMSE) and on the quest for common covariates linking NPA of AA-N, ammonia-N, and urea-N. Two covariates met these criteria: TDN concentration and NDFi. The model developed for NPA of AA-N (SE in parenthesis and $P$-value in superscript) is, therefore,

$\mathrm{NPA}$ of AA-N (g of N/d per $\mathrm{kg}$ of BW $)=-0.237^{0.011}$

$$
\begin{aligned}
& ( \pm 0.092)+0.603^{<0.001}( \pm 0.048) \times \mathrm{NI}+0.0027^{0.024} \\
& ( \pm 0.0012) \times \mathrm{TDN}-0.0053^{0.053}( \pm 0.0027) \times \mathrm{NDFi}
\end{aligned}
$$

with NI and NDFi in grams per day per kilogram of BW and TDN as \% of DM; species effect on the intercept $(P=0.010): \Delta=0.102,-0.033$, and -0.068 for sheep, cattle, and dairy cows, respectively; and RMSE $=0.0404 \mathrm{~g}$ of NPA of $\mathrm{AA}-\mathrm{N} / \mathrm{d}$ per $\mathrm{kg}$ of $\mathrm{BW} ; \mathrm{n}=$ 174 (75 experiments). Therefore, in this database, ruminants converted $60 \%$ of incremental NI into absorbed AA-N, but with the sheep presenting a higher intercept than cattle and dairy cows. Direct comparisons of NPA of AA-N in different ruminant species fed the same diets are scarce; only one study reported no difference between sheep and steers in NPA of most AA, results being expressed on a metabolic weight basis (Prior et al., 1981). However, NPA of AA in steers would have been 0.57 times the reported values if expressed on a $\mathrm{BW}^{1.0}$ basis rather than on a $\mathrm{BW}^{0.75}$ basis and, thus, absorption of most AA would have been lower in steers than in sheep. This is consistent with the finding reported in a review (Lapierre and Lobley, 2001) that sheep absorbed twice as much AA-N relative to digested $\mathrm{N}$ than cattle. In that review, AA-N relative to digested $\mathrm{N}$ was intermediate in dairy cows. However, the review could not determine whether this trend was an effect of species per se or an indirect effect of diets differing between species. The reasons for the difference observed between species in the current analysis after controlling for dietary characteristics are not clear. A higher NPA of AA-N could result from a higher supply of digestible AA due to increased rumen microbial protein synthesis or smaller losses of AA across the PDV due to either decreased oxidation or smaller losses of endogenous protein in the feces, or both. In addition, salivary urea-N secretion (approximately $60-80 \%$ of salivary $\mathrm{N}$ ) and other $\mathrm{N}$ compounds (e.g., enzymes, true proteins from mucus-producing glands, or glycoproteins) are not taken into account in PDV net flux because the salivary glands are not drained by the portal vein. Therefore, it is possible that sheep could benefit of an additional source of $\mathrm{N}$ if sheep salivate more than cattle or dairy cows when fed similar diets.

Inclusion of factors positively (TDN) or negatively (NDFi) related to the energy of the diets agrees with the fact that it is widely recognized that NI alone cannot explain protein duodenal flow and consequent NPA of AA-N due to the important contribution of microbial rumen microflora to both dietary protein degradation and microbial protein synthesis (Clark et al., 1992). Increased availability of energy stimulates microbial protein synthesis (Firkins et al., 2007), which increases the availability and absorption of AA-N. Indeed, in a study conducted to test extreme situations, NPA of AA-N was more influenced by ME intake than by $\mathrm{CP}$ concentration in cattle receiving an 11.7 or $16.2 \% \mathrm{CP}$ diet (Reynolds et al., 1992; Reynolds, 2006). Although 
the NRC (2001) system does not provide an estimate of the digestibility of energy specific to the rumen, the latter should be related to TDN diet concentration and inversely to NDFi. Indeed, concomitantly with results from Table 2, TDN had a positive relationship with NPA of AA-N, whereas the opposite was observed for NDFi. Their inclusion in the final model improved the prediction of NPA of AA-N, as the slope ( $\mathrm{g}$ of NPA of AA-N/g of NI) and RMSE (g of NPA of AA-N/d per $\mathrm{kg}$ of BW), with NI as a sole predictor, were 0.522 and 0.0432 , respectively, compared with 0.603 and 0.0404 with the inclusion of TDN and NDFi in the final model.

\section{Net Portal Appearance of Ammonia}

Influence of Covariates. The effect of species was tested within experiment with NI and the species $\times$ NI interaction. The interaction was significant $(P=0.012)$ and NPA of ammonia-N was lowest in sheep compared with cattle and dairy cows: $0.162,0.207$, and $0.204 \mathrm{~g}$ of $\mathrm{N} / \mathrm{d}$ per $\mathrm{kg}$ of BW for least squares means of ammonia$\mathrm{N}$ in sheep, cattle, and dairy cows, respectively. These least squares means were calculated at mean NI $(0.478$ $\mathrm{g} / \mathrm{d}$ per $\mathrm{kg}$ of $\mathrm{BW})$. The effect of physiological stage was not significant $(0.164$ and $0.169 \mathrm{~g}$ of $\mathrm{N} / \mathrm{d}$ per $\mathrm{kg}$ of BW for LSM of ammonia-N for growing and adult, respectively; $P=0.50$; LSM calculated at a mean NI of $0.422 \mathrm{~g} / \mathrm{d}$ per $\mathrm{kg}$ of BW). Therefore, only the interaction of species with other covariates are presented in Table 3.

All covariates had a significant influence on the effect of NI on NPA of ammonia-N but DMI (Table 3). Energy and fiber covariates had the opposite effect to what they had on NPA of AA-N: energy factors (i.e., proportion of concentrate, NFC, TDN, and NFCi) were associated negatively with NPA of ammonia-N, whereas the opposite was observed for fiber factors (i.e., NDF and NDFi). Therefore, at equal NI, provision of energy increases capture of RDP for microbial protein synthesis (see discussion above), thereby decreasing NPA of ammonia-N. Indeed, infusion of starch $(1.2 \mathrm{~kg})$ in the rumen or in the abomasum decreased NPA of ammonia-N in dairy cows (Reynolds et al., 1998), suggesting that ruminal or hindgut $\mathrm{N}$ use for fermentation was stimulated by the supply of energy.

Concentration of $\mathrm{CP}$ and of RDP (\% of DM) tended to interact with species: at a similar NI, increasing CP or RDP diet concentrations would very slightly alter the NPA of ammonia-N in the sheep, whereas it would increase NPA of ammonia- $\mathrm{N}$ in both cattle and dairy cows. It has been observed that adding dietary urea increased NPA of ammonia-N in wethers (Ferrell et al., 1999) and beef steers (Maltby et al., 2005); however NI was not constant in these studies. In addition, an increase in RDP concentration in the diet resulting from a change in feed ingredients (at a similar NI) increased ammonia absorption in wethers (Bohnert et al., 1999) and tended to increase ammonia absorption in beef heifers (Huntington, 1987); it also numerically increased ammonia- $\mathrm{N}$ absorption in dairy cows (Blouin et al., 2002).

The influence of DMI tended to differ among species, being negative in the sheep and positive in cattle and dairy cows. At similar NI, an increment in DMI implies a decreased CP concentration in the diet. As discussed above, sheep experiments with variations in $\mathrm{CP}$ and $\mathrm{NDF}$ are usually associated with a decrease in $\mathrm{CP}$ and an increase in NDF (or decrease in TDN). Therefore, an increase in DMI in sheep as opposed to cattle and dairy cows may be associated with a lack of ruminally available energy to capture RDP for microbial protein synthesis in this subdatabase.

Model of NPA of Ammonia. As observed from the subdatabases of experiments, energy and fiber covariates had the opposite effect on NPA of ammonia-N compared with NPA of AA-N, when analyzed using the whole database. Indeed, accordingly with results presented in Table 3, TDN had a negative relationship with NPA of ammonia-N, whereas the opposite was observed for NDFi. The proposed model (SE in parenthesis and $P$-value in superscript) is

$$
\begin{gathered}
\text { NPA of ammonia-N }(\mathrm{g} \text { of N } / \mathrm{d} \text { per } \mathrm{kg} \text { of } \mathrm{BW})= \\
0.169^{0.065}( \pm 0.090)+0.258^{<0.001}( \pm 0.040) \times \mathrm{NI} \\
-0.0022^{0.036}( \pm 0.0010) \times \mathrm{TDN}+0.011^{0.042}( \pm 0.005) \\
\times \mathrm{NDFi}-0.00051^{0.002}( \pm 0.00016) \times \mathrm{NDFi}^{2},
\end{gathered}
$$

with NI and NDFi in grams per day per kilogram of BW and TDN as \% of DM; species interaction on the slope of NI $(P=0.10): \Delta=-0.067,-0.054$, and 0.121 $\mathrm{g}$ of NPA of ammonia-N/g of NI for sheep, cattle, and dairy cows, respectively; and RMSE $=0.0313 \mathrm{~g}$ of NPA of ammonia-N/d per $\mathrm{kg}$ of $\mathrm{BW} ; \mathrm{n}=183$ (76 experiments). Lapierre and Lobley (2001) also reported that the slope between NPA of ammonia-N and NI was about twice as high in cattle than in sheep, but it could not be determined if this discrepancy was due to diet differences, and dairy cows were not analyzed separately from growing cattle. Results from the current metaanalysis suggest that, at constant TDN concentration and NDFi, an incremental NI would increase NPA of ammonia- $\mathrm{N}$ to a greater extent in dairy cows than in sheep and cattle.

\section{Net Portal-Drained Removal of Urea-N}

Influence of Covariates. The effect of species was significant $(P=0.04)$ as NPA of urea-N was the most 
negative in dairy cows and the less negative for cattle: $-0.154,-0.117$, and $-0.181 \mathrm{~g}$ of $\mathrm{N} / \mathrm{d}$ per $\mathrm{kg}$ of $\mathrm{BW}$ for least squares means of urea- $\mathrm{N}$ in sheep, cattle, and dairy cows, respectively. These least squares means were calculated at mean NI $(0.468 \mathrm{~g} / \mathrm{d}$ per $\mathrm{kg}$ of BW $)$. The effect of physiological stage was not significant $(-0.143$ and $-0.114 \mathrm{~g}$ of $\mathrm{N} / \mathrm{d}$ per $\mathrm{kg}$ of BW for LSM of urea-N for growing and adult, respectively; $P=0.09$; LSM calculated at a mean NI of $0.403 \mathrm{~g} / \mathrm{d}$ per $\mathrm{kg}$ of BW). Therefore, only the interaction of species with other covariates is presented in Table 4 .

Unlike the case for NPA of AA-N or ammonia-N, few covariates had a significant influence on the effect of NI on NPA of urea-N or interacted with species (Table 4). This could be partially explained by the fact that not all of the urea-N returning to the gut is accounted for by the NPA: part of the urea transfer to the gut transits via saliva (see discussion below). An energy factor like NFCi increased recycling of urea-N when controlling for NI. On the other hand, NDFi had a significant quadratic relationship. The effect of DMI mirrored that of NDFi because both covariates are correlated positively in the studies with variation of DMI and NDFi $(\mathrm{r}=0.72 ; P<0.001)$. However, it should be pointed out that ruminant studies in the subdatabase did not overlap over the full range of NDFi because only sheep studies $(\mathrm{n}=3)$ had some of their treatments with NDFi levels greater than $15 \mathrm{~g} / \mathrm{d}$ per $\mathrm{kg}$ of $\mathrm{BW}$ (none in cattle and dairy cows).

Energy factors (e.g., TDN and NFCi) were associated negatively with NPA of urea-N in line with previous studies showing that provision of rapidly fermentable energy increases the transfer of urea- $\mathrm{N}$ across the rumen wall (Kennedy and Milligan, 1980; Norton et al., 1982; Obara et al., 1991; Theurer et al., 2002). The effect of protein factors was not detected because it was already captured by NI in the residuals.

Model of NPA of Urea-N. It should be first acknowledged that this model relates only to urea-N being transferred or recycled into the gut through the PDV wall from the arterial circulation. Not all of the urea- $\mathrm{N}$ recycled into the gastrointestinal tract necessarily transits through the PDV, as a substantial flow of urea-N can be supplied to the rumen via the saliva. Low net PDV removal of urea-N may be counterbalanced by high salivary urea-N secretion. For example, the proportion of urea-N transfer through the saliva or the rumen can differ substantially depending on the type of diet (Huntington, 1989); however, the current data set could not address that aspect. The processing method and the degree of grain processing can increase the fermentation of starch in the rumen (Theurer, 1986; Huntington, 1997) and urea-N recycling to the gut (Alio et al., 2000; Delgado-Elorduy et al., 2002; Theu- rer et al., 2002). However, the data set did not contain enough experiments to control for that covariate. The proposed model (SE in parenthesis and $P$-value in superscript) including the same covariates as for AA-N and ammonia- $\mathrm{N}$ is

$$
\begin{aligned}
& \text { NPA of urea-N }(\mathrm{g} \text { of N/d per } \mathrm{kg} \text { of } \mathrm{BW})=0.304^{0.001} \\
& ( \pm 0.089)-0.107^{0.004}( \pm 0.036) \times \mathrm{NI}-0.0044^{<0.001} \\
& ( \pm 0.0010) \times \mathrm{TDN}-0.020^{<0.001}( \pm 0.005) \times \mathrm{NDFi} \\
& \quad+0.00069^{<0.001}( \pm 0.00015) \times \mathrm{NDFi}^{2}
\end{aligned}
$$

with NI and NDFi in grams per day per kilogram of $\mathrm{BW}$ and TDN as \% of DM, and RMSE $=0.0295 \mathrm{~g}$ of NPA of urea-N/d per $\mathrm{kg}$ of $\mathrm{BW} ; \mathrm{n}=163$ (70 experiments). Urea returned to the gut provides degradable $\mathrm{N}$, which can be partly used into the rumen to support microbial protein synthesis. Indeed, the recycling of urea- $\mathrm{N}$ into the gut is divided between anabolic and catabolic fates. Urea- $\mathrm{N}$ transferred to the gut and hydrolyzed into ammonia-N can be 1) used for anabolic purposes (microbial protein synthesis); 2) absorbed and returned to the ornithine cycle to resynthesize urea-N; or 3) excreted in the feces (Lapierre and Lobley, 2001). Increasing the energy supply through increased TDN is related to more negative NPA (or increased recycling) of urea-N at similar NI. This relationship is in line with previous studies showing that provision of rapidly fermentable energy increases the transfer of urea-N across the rumen wall, as previously discussed.

The effect of NDFi to decrease the NPA of urea (or increase the recycling) may be indirectly related to the effect of NDFi on NPA of ammonia-N. In experiments with a sufficient variation of NDFi, NPA of urea-N was strongly associated with NPA of ammonia-N:

$$
\begin{gathered}
\text { NPA of urea-N }=-0.072^{0.001}( \pm 0.023)-0.428^{0.002} \\
( \pm 0.128) \times \text { NPA of ammonia-N }
\end{gathered}
$$

with NPA of urea-N and ammonia-N in grams of $\mathrm{N}$ per day per kilogram of BW and RMSE $=0.0362 \mathrm{~g}$ of NPA of urea-N/d per $\mathrm{kg}$ of $\mathrm{BW} ; \mathrm{n}=48$ (20 experiments). Sunny et al. (2007) infused increasing doses of urea to increase urea entry rate and plasma concentrations without altering directly the rumen environment. They reported that urea recycled to the gastrointestinal tract was strongly correlated to plasma urea concentration, contrary to previous assumptions. Therefore, experimental conditions increasing absorption of ammonia and urea synthesis may increase recycling of urea into the gastrointestinal tract. 


\section{Linking AA-N, Ammonia-N, and Urea-N Together}

Huntington et al. (1988) suggested that good agreement could be obtained among $\mathrm{N}$ available for absorption (i.e., $\mathrm{N}$ digested + recycled urea-N) and $\mathrm{N}$ available for metabolism (i.e., NPA of AA-N + NPA of ammonia-N). Obviously, such an agreement can only be obtained if unaccounted $\mathrm{N}$ available for absorption (e.g., salivary urea-N and glycoproteins, biliary N) and for metabolism (e.g., chylomicron $\mathrm{N}$, peptides, nucleic acid, amino sugars) counterbalance each other (Martineau et al., 2009). If so, digested $\mathrm{N}$ would be equivalent to NPA of AA-N plus NPA of ammonia-N minus recycling of urea- $\mathrm{N}$ or to the summation of the 3 NPA. Furthermore, the total tract $\mathrm{N}$ apparent digestibility (TTDN) could be estimated by dividing the summation of the 3 NPA by NI.

About one-third of the treatments in the whole database did not report the $3 \mathrm{NPA}$ concurrently and were excluded from the analysis. The mean estimated TTND (i.e., summation of the 3 NPA divided by NI) was $0.52(\mathrm{SD}=0.34 ;$ minimum $=-1.03$; maximum $=$ $2.07 ; \mathrm{n}=140$ ). Such high variability could be related to measurement errors or to experimental conditions where unaccounted $\mathrm{N}$ available for both absorption and metabolism did not counterbalance. When the summation of the $3 \mathrm{NPA}$ was regressed within experiment against NI, $0.62( \pm 0.06) \mathrm{g}$ of $\mathrm{N}$ appeared as NPA of AA-N, ammonia- $\mathrm{N}$, and urea-N (or as digested $\mathrm{N}$ ) for each gram of incremental NI $(P<0.001 ; \mathrm{n}=142 ; 63$ experiments). The TTND was reported in only 27 of these 63 experiments and averaged $0.62(\mathrm{SD}=0.10$; $\mathrm{n}=82$ treatments). The lower estimation of TTDN as the summation of NPA of nitrogenous compounds divided by NI compared with measured TTDN might be related to an underestimation of NPA of ammonia-N in most of the studies where the Berthelot reaction was used to determine ammonia concentrations (Martineau et al., 2009).

\section{CONCLUSIONS}

The meta-analysis, performed on 90 experiments, indicated that the NPA of AA-N, ammonia-N, and urea-N were linearly related to NI. Also, covariates related to the energy supply of the diet, namely TDN concentration and NDFi, influenced the relationship between NI and the NPA of the 3 nitrogenous compounds. In addition to diet characteristics, species differences were detected. The NPA of AA-N responded similarly between species to incremental NI, TDN, and NDFi (no species by factor interaction), but at similar NI, TDN, and NDFi, the sheep absorbed more AA-N than did cattle and dairy cows. On the other hand, the response of NPA of ammonia-N to incremental NI tended to be twice as high in dairy cows as compared with sheep or cattle. No species difference was detected for the recycling of urea- $\mathrm{N}$ as measured by PDV flux, which excludes salivary contribution. These differences could be related to a lower loss of AA across the PDV (undigested endogenous secretions and oxidation) in sheep than in cattle. More research should be directed toward understanding the mechanisms responsible for these species differences, especially because modern diets for ruminants need to be enhanced with the goals of increasing $\mathrm{N}$ utilization efficiency, optimizing urea-N recycling, and decreasing environmental pollution associated with $\mathrm{N}$ losses.

\section{ACKNOWLEDGMENTS}

This research was undertaken thanks to funding from Dairy Farmers of Canada (Ottawa, ON), the Natural Sciences and Engineering Research Council of Canada (Ottawa, ON), and Agriculture and Agri-Food Canada (Ottawa, ON).

\section{REFERENCES}

Alio, A., C. B. Theurer, O. Lozano, J. T. Huber, R. S. Swingle, A. Delgado-Elorduy, P. Cuneo, D. DeYoung, and K. E. Webb Jr. 2000. Splanchnic nitrogen metabolism by growing beef steers fed diets containing sorghum grain flaked at different densities. J. Anim. Sci. 78:1355-1363.

Atkinson, R. L., C. D. Toone, T. J. Robinson, D. L. Harmon, and P. A. Ludden. 2007. Effects of supplemental ruminally degradable protein versus increasing amounts of supplemental ruminally undegradable protein on nitrogen retention, apparent digestibility, and nutrient flux across visceral tissues in lambs fed low-quality forage. J. Anim. Sci. 85:3331-3339.

Baird, G. D., H. W. Symonds, and R. Ash. 1974. Determination of portal and hepatic metabolite production rates in the adult dairy cow. Proc. Nutr. Soc. 33:70A-71A.

Blouin, J. P., J. F. Bernier, C. K. Reynolds, G. E. Lobley, P. Dubreuil, and H. Lapierre. 2002. Effect of supply of metabolizable protein on splanchnic fluxes of nutrients and hormones in lactating dairy cows. J. Dairy Sci. 85:2618-2630.

Bohnert, D. W., B. T. Larson, S. J. Lewis, C. J. Richards, K. C. Swanson, D. L. Harmon, and G. E. Mitchell Jr. 1999. Net nutrient flux in visceral tissues of lambs fed diets differing in supplemental nitrogen source. J. Anim. Sci. 77:2545-2553.

Branco, A. F., G. F. Mouro, D. L. Harmon, L. P. Rigolon, L. M. Zeoula, F. J. Maia, and S. M. Coneglian. 2004. Protein sources, nutrient intake and splanchnic flux of nutrients in sheep. R. Bras. Zootec. 33:444-452.

Brody, S. 1945. Bioenergetics and Growth. Reinhold, New York, NY.

Castillo, A. R., E. Kebreab, D. E. Beever, and J. France. 2000. A review of efficiency of nitrogen utilisation in lactating dairy cows and its relationship with environmental pollution. J. Anim. Feed Sci. 9:1-32.

Clark, J. H., T. H. Klusmeyer, and M. R. Cameron. 1992. Microbial protein synthesis and flows of nitrogen fractions to the duodenum of dairy cows. J. Dairy Sci. 75:2304-2323.

Cleale, R. M. IV, R. A. Britton, T. J. Klopfenstein, M. L. Bauer, D. L. Harmon, and L. D. Satterlee. 1987. Induced non-enzymatic browning of soybean meal. II. Ruminal escape and net portal absorption of soybean protein treated with xylose. J. Anim. Sci. 65:1319-1326. 
Delgado-Elorduy, A., C. B. Theurer, J. T. Huber, A. Alio, O. Lozano, M. Sadik, P. Cuneo, H. D. De Young, I. J. Simas, J. E. P. Santos, L. Nussio, C. Nussio, K. E. J. Webb Jr., and H. Tagari. 2002. Splanchnic and mammary nitrogen metabolism by dairy cows fed steam- rolled or steam-flaked corn. J. Dairy Sci. 85:160-168.

Ferrell, C. L., K. K. Kreikemeier, and H. C. Freetly. 1999. The effect of supplemental energy, nitrogen, and protein on feed intake, digestibility, and nitrogen flux across the gut and liver in sheep fed low-quality forage. J. Anim. Sci. 77:3353-3364

Firkins, J. L., Z. Yu, and M. Morrison. 2007. Ruminal nitrogen metabolism: Perspectives for integration of microbiology and nutrition for dairy. J. Dairy Sci. 90:E1-E16.

Fukuma, T., K. Taniguchi, and T. Obitsu. 2005. Evaluation of fishmeal supplement with net nitrogen flux by the portal-drained viscera and the liver in mature sheep. Asian-australas. J. Anim. Sci. 18:1255-1261.

Goetsch, A. L., and C. L. Ferrell. 1995. Effects of dietary maize level on net flux across splanchnic tissues of oxygen and nutrients in wethers consuming ad libitum different forages. Anim. Sci. 61:43-55.

Goetsch, A. L., C. L. Ferrell, and H. C. Freetly. 1994. Effects of different supplements on splanchnic oxygen consumption and net fluxes of nutrients in sheep consuming bromegrass (Bromus inermis) hay ad libitum. Br. J. Nutr. 72:701-712.

Han, X.-T., B. Xue, L. H. Hu, and J. Z. Du. 2001. Effect of dietary protein degradability on net fluxes of free and peptide amino acids across the portal-drained viscera of steers. J. Agric. Sci. 137:471481.

Huntington, G. B. 1987. Net absorption from portal-drained viscera of nitrogenous compounds by beef heifers fed on diets differing in protein solubility or degradability in the rumen. Br. J. Nutr. 57:109-114.

Huntington, G. B. 1989. Hepatic urea synthesis and site and rate of urea removal from blood of beef steers fed alfalfa hay or a high concentrate diet. Can. J. Anim. Sci. 69:215-223.

Huntington, G. B. 1997. Starch utilization by ruminants: From basics to the bunk. J. Anim. Sci. 75:852-867.

Huntington, G. B., G. A. Varga, B. P. Glenn, and D. R. Waldo. 1988. Net absorption and oxygen consumption by Holstein steers fed alfalfa or orchardgrass silage at two equalized intakes. J. Anim. Sci. 66:1292-1302

Katz, M. L., and E. N. Bergman. 1969. A method for simultaneous cannulation of the major splanchnic blood vessels of the sheep. Am. J. Vet. Res. 30:655-661.

Kennedy, P. M., and L. P. Milligan. 1980. The degradation and utilization of endogenous urea in the gastro-intestinal tract of ruminants: A review. Can. J. Anim. Sci. 60:205-221

Kleinbaum, D. G., L. L. Kupper, K. E. Muller, and A. Nizam. 1998 Confounding and interaction in regression. Pages 186-211 in Applied Regression Analysis and Other Multivariable Methods. D. G. Kleinbaum, L. L. Kupper, K. E. Muller, and A. Nizam, ed. Duxbury Press, Pacific Grove, CA.

Krehbiel, C. R., C. L. Ferrell, and H. C. Freetly. 1998. Effects of frequency of supplementation on dry matter intake and net portal and hepatic flux of nutrients in mature ewes that consume lowquality forage. J. Anim. Sci. 76:2464-2473.

Lapierre, H., R. Berthiaume, G. Raggio, M. C. Thivierge, L. Doepel, D. Pacheco, P. Dubreuil, and G. E. Lobley. 2005. The route of absorbed nitrogen into milk protein. Anim. Sci. 80:11-22.

Lapierre, H., and G. E. Lobley. 2001. Nitrogen recycling in the ruminant: A review. J. Dairy Sci. 84(Suppl.):E223-E236.

Maltby, S. A., C. K. Reynolds, M. A. Lomax, and D. E. Beever. 2005. Splanchnic metabolism of nitrogenous compounds and urinary nitrogen excretion in steers fed alfalfa under conditions of increased absorption of ammonia and L-arginine supply across the portaldrained viscera. J. Anim. Sci. 83:1075-1087.

Martineau, R., I. Ortigues-Marty, J. Vernet, and H. Lapierre. 2009. Technical note: Corrections of net portal flux of nitrogen compounds for differences in methods: First-step of a meta-analysis. J. Anim. Sci. 87:3300-3303.
Norton, B. W., J. B. Mackintosh, and D. G. Armstrong. 1982. Urea synthesis and degradation in sheep given pelleted-grass diets containing flaked barley. Br. J. Nutr. 48:249-264.

NRC. 2001. Nutrient Requirements of Dairy Cattle. 7th rev. ed. Natl. Acad. Sci., Washington, DC.

Obara, Y., D. W. Dellow, and J. V. Nolan. 1991. The influence of energy-rich supplements on nitrogen kinetics in ruminants. Pages 515-539 in Physiological Aspects of Digestion and Metabolism in Ruminants. T. Tsuda, Y. Sasaki, and R. Kawashima, ed. Academic Press, Orlando, FL

Park, K. K., A. L. Goetsch, Z. B. Johnson, and J. E. Rossi. 1997. Temporal net flux pattern of nutrients across splanchnic tissues in wethers consuming different forages. Small Rumin. Res. 25:107118.

Patil, A. R., A. L. Goetsch, K. K. Park, B. Kouakou, D. L. Galloway Sr., and Z. B. Johnson. 1995. Influence of grass source on net flux of nutrients across splanchnic tissues in sheep with restricted intake. Arch. Tierernahr. 48:257-269.

Prewitt, L. R., D. R. Jacobson, R. W. Hemken, G. D. Schelling, and R. H. Hatton. 1975. Amino acid absorption by portal-jugular venous differences in sheep fed two maturities of alfalfa hay. J. Anim. Sci. 41:1722-1727.

Prior, R. L., G. B. Huntington, and R. A. Britton. 1981. Influence of diet on amino acid absorption in beef cattle and sheep. J. Nutr. $111: 2212-2222$

Rémond, D., and C. Poncet. 2007. Partitioning of nitrogen net fluxes across the portal-drained viscera in sheep: Effect of dietary protein rumen degradability. Pages 349-350 in Energy and Protein Metabolism and Nutrition. EAAP Publ. No. 124. I. Ortigues-Marty, N. Miraux, and W. Brand-Williams, ed. Wageningen Academic Publishers, Wageningen, the Netherlands.

Reynolds, C. K. 2006. Splanchnic amino acid metabolism in ruminants. Pages 225-248 in Ruminant Physiology: Digestion, Metabolism and Impact of Nutrition on Gene Expression, Immunology and Stress. K. Sejrsen, T. Hvelplund, and M. O. Nielsen, ed. Wageningen Academic Publishers, Wageningen, the Netherlands.

Reynolds, C. K., D. P. Casper, D. L. Harmon, and C. T. Minton. 1992. Effect of $\mathrm{CP}$ and $\mathrm{ME}$ intake on visceral nutrient metabolism in beef steers. J. Anim. Sci. 70(Suppl. 1):315.

Reynolds, C. K., D. J. Humphries, S. B. Cammell, J. Benson, J. D Sutton, and D. E. Beever. 1998. Effects of abomasal wheat starch infusion on splanchnic metabolism and energy balance of lactating dairy cows. Pages 39-42 in Energy Metabolism in Farm Animals. K. J. McCracken, E. F. Unsworth, and A. R. G. Wylie, ed. CAB International, Wallingford, UK.

Reynolds, C. K., and G. B. Huntington. 1988. Partition of portaldrained visceral net flux in beef steers. 1. Blood flow and net flux of oxygen, glucose and nitrogenous compounds across stomach and post-stomach tissues. Br. J. Nutr. 60:539-551.

Sauvant, D., C. Assoumaya, S. Giger-Reverdin, and H. Archimède. 2006. Étude comparative du mode d'expression du niveau d'alimentation chez les ruminants. Congrès 13e Rencontres autour des Recherches sur les Ruminants. Institut de l'élevage, Paris, France.

Sauvant, D., P. Schmidely, J. J. Daudin, and N. R. St-Pierre. 2008. Meta-analyses of experimental data: Application in animal nutrition. Animal 2:1203-1214.

Sniffen, C. J., and D. R. Jacobson. 1975. Net amino acid absorption in steers fed alfalfa hay cut at 2 stages of maturity. J. Dairy Sci. $58: 371-385$.

Sunny, N. E., S. L. Owens, R. L. Baldwin VI, S. W. El-Kadi, R. A. Kohn, and B. J. Bequette. 2007. Salvage of blood urea nitrogen in sheep is highly dependent on plasma urea concentration and the efficiency of capture within the digestive tract. J. Anim. Sci 85:1006-1013.

Tagari, H., K. Webb Jr., B. Theurer, T. Huber, D. DeYoung, P. Cuneo, J. E. P. Santos, J. Simas, M. Sadik, A. Alio, O. Lozano, A. Delgado-Elorduy, L. Nussio, C. Nussio, and F. Santos. 2004. Portal drained visceral flux, hepatic metabolism, and mammary uptake of 
free and peptide-bound amino acids and milk amino acid output in dairy cows fed diets containing corn grain steam flaked at 360 or steam rolled at $490 \mathrm{~g} / \mathrm{L}$. J. Dairy Sci. 87:413-430.

Theurer, C. B. 1986. Grain processing effects on starch utilization by ruminants. J. Anim. Sci. 63:1649-1662.

Theurer, C. B., G. B. Huntington, J. T. Huber, R. S. Swingle, and J. A. Moore. 2002. Net absorption and utilization of nitrogenous compounds across ruminal, intestinal, and hepatic tissues of growing beef steers fed dry-rolled or steam-flaked sorghum grain. J. Anim. Sci. 80:525-532.

Vernet, J., H. Lapierre, P. Nozière, S. Léger, D. Sauvant, and I. Ortigues-Marty. 2005. Prediction of blood nutrient supply to tissues of economical interest in ruminants: A first step with the prediction of portal blood flow. Pages 163-173 in Open International Conference on Modeling and Simulation. D. R. C. Hill, V. Barra, and M. K. Traore, ed. Blaise Pascal University, Clermont-Ferrand, France.

Vernet, J., and I. Ortigues-Marty. 2006. Conception and development of a bibliographic database of blood nutrient fluxes across organs and tissues in ruminants: Data gathering and management prior to meta-analysis. Reprod. Nutr. Dev. 46:527-546.

Yan, T., J. P. Frost, R. E. Agnew, R. C. Binnie, and C. S. Mayne. 2006. Relationships among manure nitrogen output and dietary and animal factors in lactating dairy cows. J. Dairy Sci. 89:3981-3991.

\section{APPENDIX}

\section{References Used for the Meta-Analyses}

Alio, A., C. B. Theurer, O. Lozano, J. T. Huber, R. S. Swingle, A. Delgado-Elorduy, P. Cuneo, D. DeYoung, and K. E. Webb Jr. 2000. Splanchnic nitrogen metabolism by growing beef steers fed diets containing sorghum grain flaked at different densities. J. Anim. Sci. 78:1355-1363.

Archibeque, S. L., H. C. Freetly, and C. L. Ferrell. 2007. Net portal and hepatic flux of nutrients in growing wethers fed high-concentrate diets with oscillating protein concentrations. J. Anim. Sci. 85:997-1005.

Archibeque, S. L., H. C. Freetly, and C. L. Ferrell. 2008. Feeding distillers grains supplements to improve amino acid nutriture of lambs consuming moderate-quality forages. J. Anim. Sci. 86:691-701.

Atkinson, R. L., C. D. Toone, T. J. Robinson, D. L. Harmon, and P. A. Ludden. 2007. Effects of supplemental ruminally degradable protein versus increasing amounts of supplemental ruminally undegradable protein on nitrogen retention, apparent digestibility, and nutrient flux across visceral tissues in lambs fed low-quality forage. J. Anim. Sci. 85:3331-3339.

Bach, A., G. B. Huntington, S. Calsamiglia, and M. D. Stern. 2000a. Nitrogen metabolism of early lactation cows fed diets with two different levels of protein and different amino acid profiles. J. Dairy Sci. 83:2585-2595

Bach, A., G. B. Huntington, and M. D. Stern. 2000b. Response of nitrogen metabolism in preparturient dairy cows to methionine supplementation. J. Anim. Sci. 78:742-749.

Benson, J. A., C. K. Reynolds, P. C. Aikman, B. Lupoli, and D. E. Beever. 2002. Effects of abomasal vegetable oil infusion on splanchnic nutrient metabolism in lactating dairy cows. J. Dairy Sci. 85:1804-1814.

Blouin, J. P., J. F. Bernier, C. K. Reynolds, G. E. Lobley, P. Dubreuil, and H. Lapierre. 2002. Effect of supply of metabolizable protein on splanchnic fluxes of nutrients and hormones in lactating dairy cows. J. Dairy Sci. 85:2618-2630.

Bohnert, D. W., B. T. Larson, S. J. Lewis, C. J. Richards, K. C Swanson, D. L. Harmon, and G. E. Mitchell Jr. 1999. Net nutrient flux in visceral tissues of lambs fed diets differing in supplemental nitrogen source. J. Anim. Sci. 77:2545-2553.

Branco, A. F., G. F. Mouro, D. L. Harmon, L. P. Rigolon, L. M. Zeoula, F. J. Maia, and S. M. Coneglian. 2004. Protein sources, nutrient intake and splanchnic flux of nutrients in sheep. R. Bras. Zootec. 33:444-452.
Cleale, R. M., IV, R. A. Britton, T. J. Klopfenstein, M. L. Bauer, D. L. Harmon, and L. D. Satterlee. 1987. Induced non-enzymatic browning of soybean meal. II. Ruminal escape and net portal absorption of soybean protein treated with xylose. J. Anim. Sci. 65:1319-1326.

De Visser, H., H. Valk, A. Klop, J. Van der Meulen, J. G. M. Bakker, and G. B. Huntington. 1997. Nutrient fluxes in splanchnic tissue of dairy cows: Influence of grass quality. J. Dairy Sci. 80:1666-1673.

Del Sole, M. J., M. I. Recavarren, and G. D. Milano. 2004. Splanchnic energy expenditure and net nutrient flux in sheep fed diets with varying concentrate:forage ratios. J. Anim. Feed Sci. 13:307-310.

Delgado-Elorduy, A., C. B. Theurer, J. T. Huber, A. Alio, O. Lozano, M. Sadik, P. Cuneo, H. D. De Young, I. J. Simas, J. E. P. Santos, L. Nussio, C. Nussio, K. E. Webb Jr., and H. Tagari. 2002a. Splanchnic and mammary nitrogen metabolism by dairy cows fed dry-rolled or steam-flaked sorghum grain. J. Dairy Sci. 85:148-159.

Delgado-Elorduy, A., C. B. Theurer, J. T. Huber, A. Alio, O. Lozano, M. Sadik, P. Cuneo, H. D. De Young, I. J. Simas, J. E. P. Santos, L. Nussio, C. Nussio, K. E. Webb Jr., and H. Tagari. 2002b. Splanchnic and mammary nitrogen metabolism by dairy cows fed steam-rolled or steam-flaked corn. J. Dairy Sci. 85:160-168.

Eisemann, J. H., G. B. Huntington, and D. R. Catherman. 1996. Patterns of nutrient interchange and oxygen use among portal-drained viscera, liver, and hindquarters of beef steers from 235 to $525 \mathrm{~kg}$ body weight. J. Anim. Sci. 74:1812-1831.

Ferrell, C. L., K. K. Kreikemeier, and H. C. Freetly. 1999. The effect of supplemental energy, nitrogen, and protein on feed intake, digestibility, and nitrogen flux across the gut and liver in sheep fed low-quality forage. J. Anim. Sci. 77:3353-3364.

Freetly, H. C. and C. L. Ferrell. 1998. Net flux of glucose, lactate, volatile fatty acids, and nitrogen metabolites across the portal-drained viscera and liver of pregnant ewes. J. Anim. Sci. 76:3133-3145.

Fukuma, T., K. Taniguchi, and T. Obitsu. 2005. Evaluation of fishmeal supplement with net nitrogen flux by the portal-drained viscera and the liver in mature sheep. Asian-australas. J. Anim. Sci. 18:1255-1261.

Goetsch, A. L. and C. L. Ferrell. 1995. Effects of dietary maize level on net flux across splanchnic tissues of oxygen and nutrients in wethers consuming ad libitum different forages. Anim. Sci. 61:43-55.

Goetsch, A. L., C. L. Ferrell, and H. C. Freetly. 1994. Effects of different supplements on splanchnic oxygen consumption and net fluxes of nutrients in sheep consuming bromegrass (Bromus inermis) hay ad libitum. Br. J. Nutr. 72:701-712.

Goetsch, A. L., A. R. Patil, D. L. Galloway, B. Kouakou, Z. S. Wang, K. K. Park, and J. E. Rossi. 1997a. Net flux of nutrients across splanchnic tissues in wethers consuming grasses of different sources and physical forms ad libitum. Br. J. Nutr. 77:769-781.

Goetsch, A. L., A. R. Patil, Z. S. Wang, K. K. Park, D. L. Galloway Sr., J. E. Rossi, and B. Kouakou. 1997b. Net flux of nutrients across splanchnic tissues in wethers consuming bermudagrass or ryegrass-wheat hay supplemented with rumen undegradable protein. Small Rumin. Res. 25:119-128.

Goetsch, A. L., A. R. Patil, Z. S. Wang, K. K. Park, D. L. Galloway Sr., J. E. Rossi, and B. Kouakou. 1997c. Net flux of nutrients across splanchnic tissues in wethers consuming grass hay with or without corn and alfalfa. Anim. Feed Sci. Technol. 66:271-282.

Hammon, H. M., C. C. Metges, P. Junghans, F. Becker, O. Bellmann, F. Schneider, G. Nürnberg, P. Dubreuil, and H. Lapierre. 2008. Metabolic changes and net portal flux in dairy cows fed a ration containing rumen-protected fat as compared with a control diet. J. Dairy Sci. 91:208-217.

Han, X.-T., P. Nozière, D. Rémond, J. Chabrot, and M. Doreau. 2002. Effects of nutrient supply and dietary bulk on $\mathrm{O}_{2}$ uptake and nutrient net fluxes across rumen, mesenteric- and portal-drained viscera in ewes. J. Anim. Sci. 80:1362-1374.

Han, X.-T., B. Xue, L.-H. Hu, and J.-Z. Du. 2001. Effect of dietary protein degradability on net fluxes of free and peptide amino acids across the portal-drained viscera of steers. J. Agric. Sci. 137:471481.

Huntington, G. B. 1983. Net nutrient absorption in beef steers fed silage or high concentrate diets containing four levels of limestone. J. Nutr. 113:1157-1164. 
Huntington, G. B. 1987. Net absorption from portal-drained viscera of nitrogenous compounds by beef heifers fed on diets differing in protein solubility or degradability in the rumen. Br. J. Nutr. $57: 109-114$.

Huntington, G. B. 1989. Hepatic urea synthesis and site and rate of urea removal from blood of beef steers fed alfalfa hay or a high concentrate diet. Can. J. Anim. Sci. 69:215-223.

Huntington, G. B. and R. L. Prior. 1983. Digestion and absorption of nutrients by beef heifers fed a high concentrate diet. J. Nutr. 113:2280-2288.

Huntington, G. B., G. A. Varga, B. P. Glenn, and D. R. Waldo. 1988. Net absorption and oxygen consumption by Holstein steers fed alfalfa or orchardgrass silage at two equalized intakes. J. Anim. Sci. 66:1292-1302.

Huntington, G. B., E. J. Zetina, J. M. Whitt, and W. Potts. 1996. Effects of dietary concentrate level on nutrient absorption, liver metabolism, and urea kinetics of beef steers fed isonitrogenous and isoenergetic diets. J. Anim. Sci. 74:908-916.

Kraft, G., I. Ortigues-Marty, and I. Savary-Auzeloux. 2007. Splanchnic net release and body retention of nitrogen in growing lambs fed diets unbalanced for energy and protein. Pages 347-348 in Energy and Protein Metabolism and Nutrition. EAAP Publ. No. 124. I. Ortigues-Marty, N. Miraux, W. Brand-Williams, ed. Wageningen Academic Publishers, Wageningen, the Netherlands.

Krehbiel, C. R., C. L. Ferrell, and H. C. Freetly. 1998. Effects of frequency of supplementation on dry matter intake and net portal and hepatic flux of nutrients in mature ewes that consume lowquality forage. J. Anim. Sci. 76:2464-2473.

Lapierre, H., J. F. Bernier, P. Dubreuil, C. K. Reynolds, C. Farmer, D. R. Ouellet, and G. E. Lobley. 2000. The effect of feed intake level on splanchnic metabolism in growing beef steers. J. Anim. Sci. 78:1084-1099.

Lapierre, H., D. R. Ouellet, R. Berthiaume, C. Girard, P. Dubreuil, M. Babkine, and G. E. Lobley. 2004. Effect of urea supplementation on urea kinetics and splanchnic flux of amino acids in dairy cows. J. Anim. Feed Sci. 13(Suppl.1):319-322.

Lapierre, H., C. K. Reynolds, T. H. Elsasser, P. Gaudreau, P. Brazeau, and H. F. Tyrrell. 1992. Effects of growth hormone-releasing factor and feed intake on energy metabolism in growing beef steers: Net hormone metabolism by portal-drained viscera and liver. J. Anim. Sci. 70:742-751.

MacRae, J. C., L. A. Bruce, D. S. Brown, D. A. Farningham, and M. Franklin. 1997. Absorption of amino acids from the intestine and their net flux across the mesenteric- and portal-drained viscera of lambs. J. Anim. Sci. 75:3307-3314.

Maltby, S. A., L. A. Crompton, M. A. Lomax, D. E. Beever, and C. J. Pippard. 1993. The effect of increased ammonia supply on postprandial hepatic metabolism in growing steers fed either forage or cereal-based diets. Proc. Nutr. Soc. 52:295A.

Maltby, S. A., M. A. Lomax, D. E. Beever, and C. J. Pippard. 1992. The effect of increased ammonia and amino acid supply on post prandial portal-drained viscera and hepatic metabolism in growing steers fed maize silage. Pages 20-23 in EAAP Publ. No. 58. C. Wenk and M. Boessinger, ed. ETH, Zurich, Switzerland.

Maltby, S. A., C. K. Reynolds, M. A. Lomax, and D. E. Beever. 2005. Splanchnic metabolism of nitrogenous compounds and urinary nitrogen excretion in steers fed alfalfa under conditions of increased absorption of ammonia and L-arginine supply across the portaldrained viscera. J. Anim. Sci. 83:1075-1087.

McGuire, M. A., D. K. Beede, M. A. DeLorenzo, C. J. Wilcox, G. B. Huntington, C. K. Reynolds, and R. J. Collier. 1989. Effects of thermal stress and level of feed intake on portal plasma flow and net fluxes of metabolites in lactating Holstein cows. J. Anim. Sci. 67:1050-1060.

Mouro, G. F., A. F. Branco, D. L. Harmon, F. J. Maia, S. M. Coneglian, and T. F. M. Ribeiro. 2006. Carbohydrate sources and ionophore in sheep diets with vegetal oil: Digestibility, nitrogen balance and portal flux of nutrients. R. Bras. Zootec. 35:2144-2153.

Nozière, P., D. Rémond, L. Bernard, and M. Doreau. 2000. Effect of underfeeding on metabolism of portal-drained viscera in ewes. Br. J. Nutr. 84:821-828.
Nozière, P., D. Rémond, S. Lemosquet, B. Chauveau, D. Durand, and C. Poncet. 2005. Effect of site of starch digestion on portal nutrient net fluxes in steers. Br. J. Nutr. 94:182-191.

Ortigues, I., A.-L. Visseiche, and D. Durand. 1994. Adaptation to undernutrition in ewes: Net nutrient fluxes across the portal-drained viscera, the liver and the hindquarters. Pages 89-92 in EAAP Publ. No. 76. J. F. Aguilera, ed. CSIC, Granada, Spain.

Park, K. K., A. L. Goetsch, Z. B. Johnson, and J. E. Rossi. 1997. Temporal net flux pattern of nutrients across splanchnic tissues in wethers consuming different forages. Small Rumin. Res. 25:107118.

Patil, A. R., A. L. Goetsch, K. K. Park, B. Kouakou, D. L. Galloway Sr., and Z. B. Johnson. 1995. Influence of grass source on net flux of nutrients across splanchnic tissues in sheep with restricted intake. Arch. Tierernahr. 48:257-269.

Patil, A. R., A. L. Goetsch, K. K. Park, B. Kouakou, D. L. Galloway Sr., and Z. B. Johnson. 1996. Influence of grass source and legume level on net flux of nutrients across splanchnic tissues in sheep. Small Rumin. Res. 22:111-122.

Patil, A. R., A. L. Goetsch, K. K. Park, B. Kouakou, D. L. Galloway Sr., C. P. West, and Z. B. Johnson. 1995. Net flux of nutrients across splanchnic tissues in sheep fed tropical vs. temperate grass hay of moderate or low qualities. Livest. Prod. Sci. 43:49-61.

Prewitt, L. R., D. R. Jacobson, R. W. Hemken, G. D. Schelling, and R. H. Hatton. 1975. Amino acid absorption by portal-jugular venous differences in sheep fed two maturities of alfalfa hay. J. Anim. Sci. 41:1722-1727.

Prior, R. L., G. B. Huntington, and R. A. Britton. 1981. Influence of diet on amino acid absorption in beef cattle and sheep. J. Nutr. 111:2212-2222.

Raggio, G., D. Pacheco, R. Berthiaume, G. E. Lobley, D. Pellerin, G. Allard, P. Dubreuil, and H. Lapierre. 2004. Effect of level of metabolizable protein on splanchnic flux of amino acids in lactating dairy cows. J. Dairy Sci. 87:3461-3472.

Rémond, D., and C. Poncet. 2007. Partitioning of nitrogen net fluxes across the portal-drained viscera in sheep: Effect of dietary protein rumen degradability. Pages 349-350 in Energy and Protein Metabolism and Nutrition. EAAP Publ. No. 124. I. Ortigues-Marty, N. Miraux, and W. Brand-Williams, ed. Wageningen Academic Publishers, Wageningen, the Netherlands.

Reynolds, C. K., J. A. Benson, P. C. Aikman, B. Lupoli, M. D. Hanigan, D. E. Beever, and J. C. MacRae. 2003. Effects of diet forage:concentrate ratio on splanchnic nutrient metabolism in lactating dairy cows. J. Dairy Sci. 86(Suppl.1):219.

Reynolds, C. K., B. J. Bequette, J. S. Caton, D. J. Humphries, B. Lupoli, and J. D. Sutton. 2001. Effects of intake and lactation on absorption and metabolism of leucine and phenylalanine by splanchnic tissues of dairy cows. J. Dairy Sci. 84(Suppl. 1):362.

Reynolds, C. K., D. P. Casper, D. L. Harmon, and C. T. Minton. 1992 Effect of $\mathrm{CP}$ and $\mathrm{ME}$ intake on visceral nutrient metabolism in beef steers. J. Anim. Sci. 70(Suppl. 1):315.

Reynolds, C. K., D. J. Humphries, S. B. Cammell, J. Benson, J. D Sutton, and D. E. Beever. 1998. Effects of abomasal wheat starch infusion on splanchnic metabolism and energy balance of lactating dairy cows. Pages 39-42 in Energy Metabolism in Farm Animals. K. J. McCracken, E. F. Unsworth, and A. R. G. Wylie, ed. CAB International, Wallingford, UK.

Reynolds, C. K., and G. B. Huntington. 1988. Partition of portaldrained visceral net flux in beef steers. 1. Blood flow and net flux of oxygen, glucose and nitrogenous compounds across stomach and post-stomach tissues. Br. J. Nutr. 60:539-551.

Reynolds, C. K., G. B. Huntington, H. F. Tyrrell, and P. J. Reynolds. 1988. Net portal-drained visceral and hepatic metabolism of glucose, L-lactate, and nitrogenous compounds in lactating Holstein cows. J. Dairy Sci. 71:1803-1812.

Reynolds, C. K. and H. F. Tyrrell. 1991. Effects of mesenteric vein L-alanine infusion on liver metabolism in beef heifers fed on diets differing in forage:concentrate ratio. Br. J. Nutr. 66:437-450.

Reynolds, C. K., H. F. Tyrrell, and P. J. Reynolds. 1991. Effects of diet forage-to-concentrate ratio and intake on energy metabolism 
in growing beef heifers: Whole body energy and nitrogen balance and visceral heat production. J. Nutr. 121:994-1003.

Savary-Auzeloux, I., L. Majdoub, N. Le Floc'h, and I. Ortigues-Marty. 2003. Ryegrass-based diet and barley supplementation: Partition of nitrogenous nutrients among splanchnic tissues and hind limb in finishing lambs. J. Anim. Sci. 81:3160-3173.

Seal, C. J., D. S. Parker, and P. J. Avery. 1992. The effect of forage and forage-concentrate diets on rumen fermentation and metabolism of nutrients by the mesenteric- and portal-drained viscera in growing steers. Br. J. Nutr. 67:355-370.

Sniffen, C. J. and D. R. Jacobson. 1975. Net amino acid absorption in steers fed alfalfa hay cut at two stages of maturity. J. Dairy Sci. 58:371-385.
Tagari, H. and E. N. Bergman. 1978. Intestinal disappearance and portal blood appearance of amino acids in sheep. J. Nutr. 108:790803

Theurer, C. B., G. B. Huntington, J. T. Huber, R. S. Swingle, and J. A. Moore. 2002. Net absorption and utilization of nitrogenous compounds across ruminal, intestinal, and hepatic tissues of growing beef steers fed dry-rolled or steam-flaked sorghum grain. J. Anim. Sci. 80:525-532. 